\title{
NON-GAAP FINANCIAL MEASURES: EVIDENCE FROM CANADA
}

\author{
By \\ Sameera Hassan \\ MBA (Finance), 2006 \\ Institute of Business Administration, Karachi \\ Bachelor of Commerce, 2004 \\ Karachi University
}

\begin{abstract}
A thesis presented to
Ryerson University

in partial fulfillment of the

requirements for the degree of

Master of Science in Management

in the program of

Master of Science in Management

Toronto, Ontario, Canada, 2019
\end{abstract}

CSameera Hassan, 2019 


\section{Authors Declaration:}

I hereby declare that I am the sole author of this thesis. This is a true copy of the thesis, including any required final revisions, as accepted by my examiners.

I authorize Ryerson University to lend this thesis to other institutions or individuals for the purpose of scholarly research.

I further authorize Ryerson University to reproduce this thesis by photocopying or by other means, in total or in part, at the request of other institutions or individuals for the purpose of scholarly research.

I understand that my thesis may be made electronically available to the public.

Sameera Hassan

April 22, 2019 


\title{
NON-GAAP FINANCIAL MEASURES: EVIDENCE FROM \\ CANADA
}

\author{
Sameera Hassan \\ Master of Science in Management \\ Ted Rogers School of Management \\ Ryerson University \\ 2019
}

\begin{abstract}
:
This paper investigates non-GAAP financial measures voluntarily reported by Canadian companies listed on Toronto stock exchange (TSX) and Toronto Ventures Exchange (TSXV) for the year 2017. Non-GAAP measures are those that do not adhere to the requirements of generally accepted accounting principles (GAAP) and are used to communicate those aspects of firms' operations which the firms see as relevant for the users of financial statements. This study is an exploratory research which describes current firm practices in reporting non-GAAP financial measures among three industry groups, namely Real Estate, Blockchain/Cryptocurrency and Cannabis firms. This paper also assesses the quality of non-GAAP financial disclosures in accordance with the regulatory guidance. The study is motivated by recent regulatory proposals issued by the Canadian Securities Administrators (CSA), under the National Instrument NI 52-112 and by the Accounting Standards Board (AcSB) pertaining to reporting non-GAAP performance measures. The main contribution of this study is a detailed content analysis of a sample of Canadian firms. My analysis of hand collected data from the Management Discussion and Analysis (MD\&A) indicates a plethora of reported "non-GAAP financial measures" disclosed by companies. The analysis also indicates that firms are falling short on parameters such as understandability, comparability, standardization, consistency and persistence of non-GAAP financial measures which are essential under the existing guidelines, and that regulation of non-GAAP financial measures would be beneficial. The study's findings may be relevant to regulators for formulating guidance on reporting non-GAAP measures and identifies areas of potential future studies in the area of non-GAAP financial measures.
\end{abstract}

Keywords: Non-GAAP financial measures, Non-GAAP earnings, Pro forma earnings, Non-IFRS measures, Street earnings, Core earnings, Adjusted earnings and NI 52-112. 


\section{TABLE OF CONTENTS}

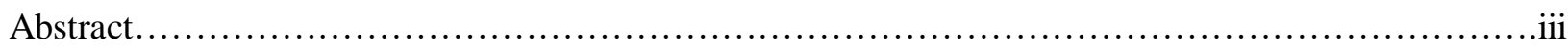

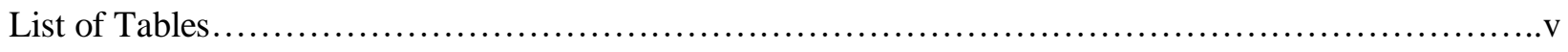

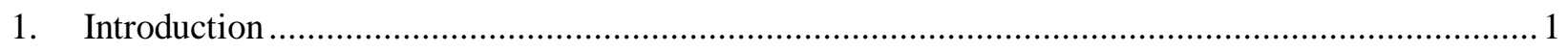

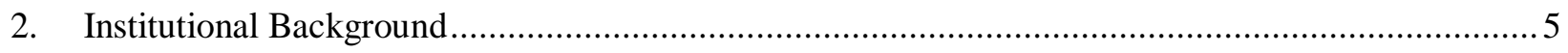

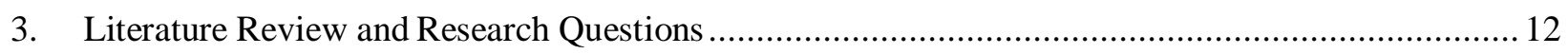

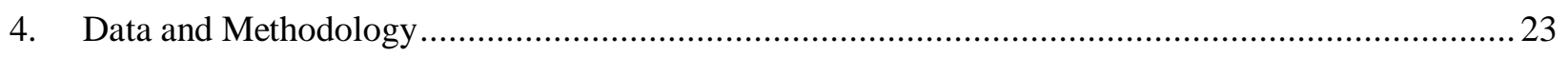

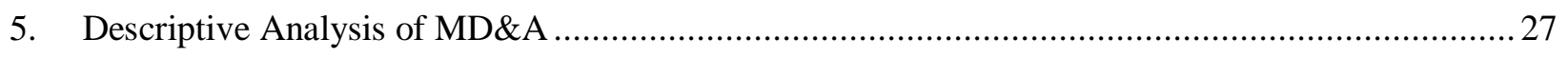

Use of non-GAAP financial measures and adjustment analysis................................................... 27

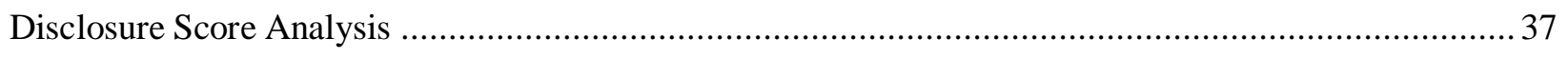

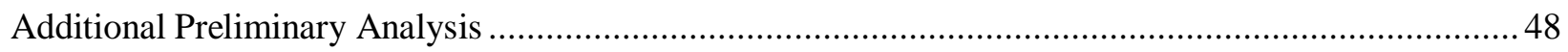

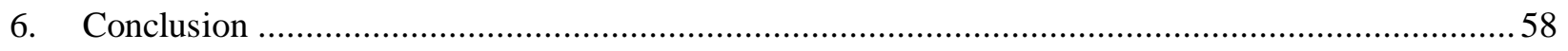

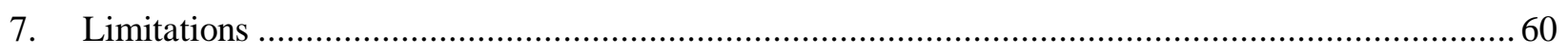

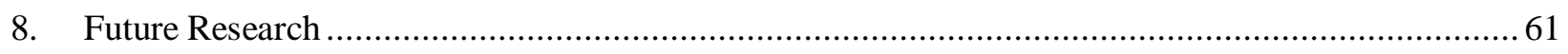

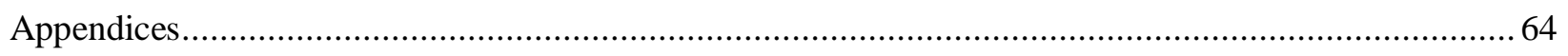

Appendix A - Distribution of the 74 Reported non-GAAP Financial Measures observed in Study's

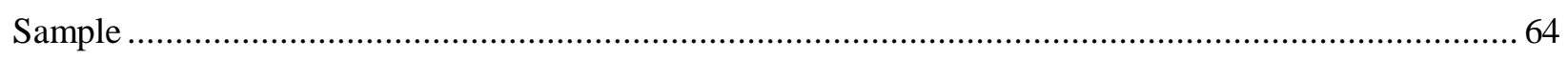

Appendix B - Tables of Adjustments to Selected Common non-GAAP financial measures ....................67

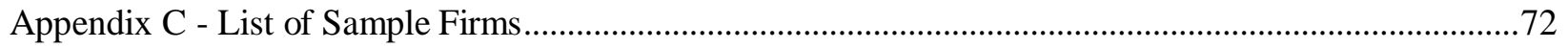

Appendix D - Sample Management Discussion and Analysis Disclosure Scoring ................................76

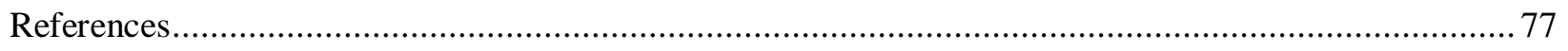




\section{LIST OF TABLES}

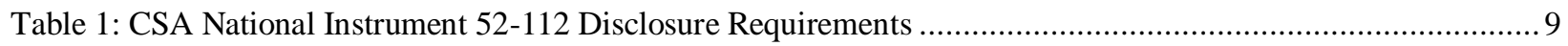

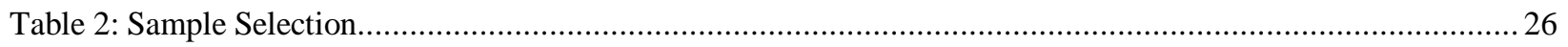

Table 3: Selected Frequencies of non-GAAP financial measures with industry breakdown ...................................29

Table 4: Analysis of types of adjustments used to compute adjusted EBITDA.................................................... 30

Table 5: Analysis of types of adjustments used to compute Free Cash Flows (FCF)......................................... 31

Table 6: Analysis of types of adjustments used to compute Funds from Operations (FFO) …….......................... 32

Table 7: Analysis of types of adjustments used to compute Net Operating Income (NOI) .................................... 33

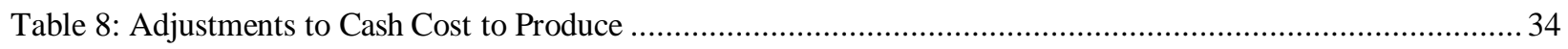

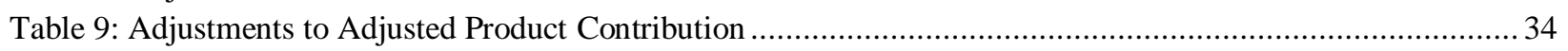

Table 10: Descriptive Statistics for Disclosure scores of firms' non-GAAP Financial measures............................. 38

Table 11: Disclosure scores for 43 Firms disclosing non-GAAP Financial measures across 24 Parameters ............. 39

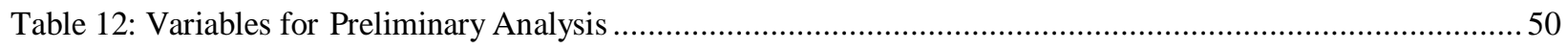

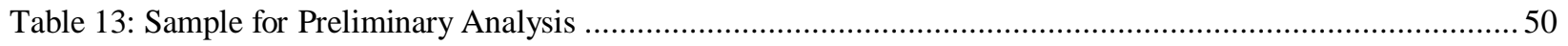

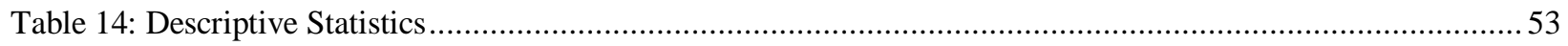

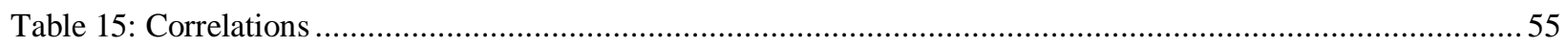

Table 16: Relation between Non-GAAP financial measures, Analyst following, Profits/Loss and Disclosure Score 57 


\section{INTRODUCTION}

The aim of this study is to examine the current disclosure practices and quality of a specific kind of accounting information and financial measure, namely non-GAAP financial measures disclosed by publicly listed companies in Canada. Companies commonly supplement their earnings, prepared under GAAP, by reporting various non-standardized performance measures in their Management Discussion \& Analysis (MD\&A). The supplemental measures could be financial or non-financial, however, the focus of this study is only the non-GAAP "financial" types of measures. Non-GAAP financial measures are information items that do not adhere to generally accepted accounting principles ("GAAP") and are used to communicate those aspects of firms' operations which the firms see as relevant for its stakeholders. Non-GAAP financial measures are voluntarily reported, disclosed and presented as part of the annual reports of a company and are useful in decision-making by stakeholders and users of financial statements (Albring et al., 2010).

The goal of this study is to augment our understanding of non-GAAP financial measures by reviewing the institutional background and relevant prior literature, examining a sample of Canadian public companies' annual reports to identify uses of non-GAAP financial disclosures, and performing a content analysis to assess the quality of this disclosure.

The impetus for this study comes from capital markets regulators, who recently have expressed reservations about the consistency, transparency and comparability of non-GAAP financial measures and are concerned that these measures can be misleading. The primary motivation comes from two recent Canadian regulatory proposals pertaining to disclosure requirements for reporting non-GAAP performance measures. One proposal is issued by the Canadian Accounting Standards Board (Draft Framework for Reporting Performance Measures (AcSB, 2018)), and the other issued by the Canadian Securities 

continuous disclosure review program findings “(NI 51-355: Continuous Disclosure Review Program Activities for the fiscal years ended March 31, 2018 and March 31, 2017” (CSA, 2018b)) outlines the quality of non-GAAP financial measures' and the disclosures pertaining to non-GAAP financial measures as an area of concern for publicly listed companies, providing further incentive to undertake this study. Foreseeable potential changes in the regulation of non-GAAP measures and increases in scrutiny make nonGAAP financial disclosure an important area of attention for Canadian researchers, practitioners, and regulators.

Given the increasing frequency of non-GAAP financial measures being disclosed by Canadian firms, and these expected changes in the reporting and regulatory environment related to this type of information, this study provides a timely examination of the nature and quality of non-GAAP financial disclosures. This is a novel area of research in Canada, and the findings of this study will identify areas to research in future research. Another valuable contribution of this study is to highlight areas for regulators to consider when formulating enforceable regulations around non-GAAP financial measures in Canada.

Based on an extensive review of the literature related to this topic, I find that non-GAAP earnings are of interest to many stakeholders, including regulators, analysts, investors, and firms, indicating that they are useful and relevant, and thus informative. Few studies examine in detail which measures are commonly reported and what adjustments are made to calculate the non-GAAP financial measures, however. In addition, Canadian companies have not been examined in depth, as the current literature is focused mostly on US companies. To address these gaps in the literature, this study pursues two main research objectives. First, it seeks to describe current practice by Canadian firms in selected industry groups when they report and disclose non-GAAP financial measures, and to analyze the common types of adjustments they make to the GAAP numbers. Second, it aims to evaluate the quality of Canadian firms' current non-GAAP financial measures by assessing the disclosures against guidance established by Canadian regulators, using these guidelines to construct a disclosure quality score. 
For the purpose of this research, a sample of 75 firms from the Toronto Stock Exchange (TSX) and Toronto Ventures Exchange (TSXV) listings as of September 2018 has been selected for study. The sample selection is focused on three of the industry groups that have been identified and highlighted by the Canadian Securities Administrators (CSA) as emerging and high-risk industries in the CSA's continuous disclosure review program, these three being the Real Estate, Cannabis, and Blockchain/Cryptocurrency industry groups. (CSA, 2018b). Sample companies from these three industry groups ${ }^{1}$ were identified using the industry sector and sub-sectors classification in the TSX public company listings as of September 2018. Analysis of hand collected data from the sample companies' Management Discussion and Analysis (MD\&A) for their 2017 fiscal year indicates that 41 of the 75 sample companies disclosed non-GAAP financial measures. The disclosure details were analyzed for each sample firm that disclosed non-GAAP financial measures and coded to assign a disclosure quality score. This analysis indicates that firms are falling short on parameters such as understandability, clarity, comparability, standardization, and persistence.

In contrast to the studies investigating the informational role of voluntary non-GAAP financial disclosures, prior theoretical and empirical studies have also examined the possibility that these disclosures may be used opportunistically by management, to manipulate investors' impressions of the company's performance. To extend this line of research, in this study I follow up the findings of the descriptive analysis with additional preliminary tests examining whether the choice to report non-GAAP financial measures and quality of these measures is associated with analyst following. The preliminary findings suggest that higher analyst following is associated with firms' choice to disclose non-GAAP financial measures, as well as quality of non-GAAP disclosures, consistent with the view that non-GAAP financial measures are informative rather than manipulative, however, due to sample limitations and related econometric issues in

\footnotetext{
${ }^{1}$ The industry group definitions and classification used in this study are based on TSX sector and sub-sector classifications that most closely aligns with the CSA's industry identifiers and may be labelled in another sector or sub-sector. Note that these industry group definitions may not be comparable to other studies that use Global Industry Classification System (GICS) or (North American Industry Classification system (NAICS) industry classifiers or any other methods.
} 
this study, these findings lack robustness. They included only as a starting point for future, more rigorous study of the motivations behind firms' choice to disclose non-GAAP financial measures.

The rest of this paper is organized in the following manner. Section 2 presents the institutional background outlining the proliferation of non-GAAP financial measures and regulatory responses over the years. A detailed literature review on the subject is presented in section 3, identifying gaps in existing research and developing the study's research questions. Section 4 discusses the data collection methodology with detailed analysis and findings reported in section 5. The thesis paper culminates with conclusions discussed in section 6. Limitations and areas with potential for further research are elaborated in section 7 and 8 , respectively. 


\section{INSTITUTIONAL BACKGROUND}

The impetus behind this research is the growing interest of regulators and researchers in non-GAAP measures. At the outset, it is important to note the distinction between non-GAAP financial measures and other types of performance metrics which firms report to their stakeholders. Companies commonly supplement and explain their reported bottom line earnings, prepared under GAAP, with non-GAAP performance measures which they believe are more meaningful than GAAP measures to reflect their core operations or true financial position (Venter, 2014). These non-standardized performance measures could be financial or non-financial. Non-GAAP non-financial measures also can provide relevant information to help decision making (Cole and Jones, 2005). For example, Marques (2006) explores non-GAAP nonfinancial measures such as web traffic for online platforms, footfall for retail store, shelf life for consumer products etc., which are commonly reported by firms in their MD\&A to signal and differentiate themselves from their peers in the industry.

The focus of this study is only the non-GAAP financial types of measures, however. A non-GAAP financial measure is defined here as one that: is derived from GAAP measures as a result of adjustments made to GAAP numbers, is represented with a dollar value, and, could be reconciled back to the GAAP number. There are other synonyms for non-GAAP financial or earnings measures, such as "Pro forma earnings" (commonly referred to in Canada), "non-IFRS earnings", "adjusted earnings", "Core earnings" and "Street earnings". Hereinafter, the term "non-GAAP financial measure" will be used throughout this paper.

Also, for the purpose of this paper, the Canadian Securities Administrators (CSA) and Canada's Accounting Standards Board (AcSB) hereafter will be referred to as "regulators", given both organizations have the role of developing generally accepted guidelines for the financial reporting that is required by publicly listed companies in Canada under provincial securities laws. Further, CSA and AcSB guidelines ultimately can become the basis of regulations that are enforced in Canada through provincial securities laws by the CSA. Thus, I take the view in this study that these two organizations serve a regulatory role related to the study's area of interest. 
The historical development of non-GAAP performance reporting starts in the late 1990's when an unprecedented increase in non-GAAP performance measures in the United States (US) was witnessed. During this period, the US Securities Exchange Commission (SEC) issued guidelines in an attempt to regulate non-GAAP financial measures, in reaction to perceived misreporting done through non-GAAP financial measures, and to make them more informative and to protect investors. The process took place over several phases.

The first SEC guideline issued around non-GAAP disclosures was called Regulation G, issued in 2003 (SEC, 2003). The latest update to Regulation G comes in the form of Compliance and Disclosure Interpretations (CD\&I) (SEC, 2016). The core intent of these regulations is to make sure that the reported non-GAAP financial measures are disclosed transparently. Also, equal emphasis is to be made on GAAP and non-GAAP financial measures when reporting in earnings announcements, press releases or on social media (SEC, 2016). CD\&I additionally calls for companies that report non-GAAP financial measures to also provide a reconciliation with the related GAAP-based financial measure. Substantial research has been done on the effect of these interventions in the US markets, with mixed findings related to the effectiveness of these regulations (e.g., Lee and Chu, 2016; Bond et al., 2017).

Since there were no enforceable regulations in Canada at the time, there are no comparable studies done on Canadian firms. However, developments have been catching up in the domain of non-GAAP financial measures in Canada as well. The first guidance came from the CSA ${ }^{2}$ in 2003 in form of CSA Staff Notice 52-306 (CSA, 2003b) as part of the continuous disclosure obligations laid out by the CSA in National Instrument, NI 51-102 (CSA, 2003a), which requires timely disclosure of material changes to financial statements and the MD\&A. However, due to the broad scope of NI 51-102 more specific guidelines on nonGAAP financial measures were imperative, which the CSA issued as Staff Notice 52-306. Staff Notice 52306 defined a non-GAAP financial measure as:

\footnotetext{
${ }^{2}$ The CSA is a Canada-wide umbrella organization under which securities regulators from the 10 provinces and 3 territories have come together with the common objective of creating harmonized regulation and fostering efficient operation of securities markets in Canada. CSA's regulations are enforced by securities commissions in the provinces and territories, which have jurisdiction over securities regulation in Canada (www.securities-administrators.ca).
} 
"a numerical measure of an issuer's historical or future financial performance, financial position or cash flow, that is not required by GAAP, that (i) either excludes amounts that are included in the most directly comparable measure calculated and presented in accordance with GAAP; or (ii) includes amounts that are excluded from the most directly comparable measure calculated and presented in accordance with GAAP.” (CSA, 2003b, p. 2)

One important distinction to make at this point is that Staff Notices issued by CSA are just guidelines recommended to improve financial reporting, whereas National Instruments are enforceable regulatory instruments and must be adhered to. This is further discussed in light of the study's results and findings.

Staff Notice 52-306 originally had five main guidelines for non-GAAP financial measures. This number has increased as more issues have been identified and as Staff Notice 52-306 has been revised. The first revision was in 2010 to clarify expectations for reporting non-GAAP financial measures in light of Canada's planned adoption of International Financial Reporting Standards (IFRS) as GAAP for publicly listed companies. It was also stipulated that the press releases, websites, and other media used to disclose non-GAAP financial measures should also follow these guidelines. A second revision came in 2012 giving more guidance after the adoption of IFRS with respect to concerns around what constitutes non-GAAP financial measures and providing more clarity and guidance for preparing financial statements (CSA, 2010). The latest revision was issued in 2016 where two more guidelines were added to the already existing five guidelines (CSA, 2016). The new additions were with respect to the consistency of non-GAAP financial measures, and the inclusion and exclusion of infrequent items; which states that an entity shall present and report all additional line items, gains, losses and other comprehensive income that are relevant and important to understand an entity's financial performance (CSA, 2016). This guidance has a two-fold impact. On one hand, it gives firms the flexibility to determine what is 'relevant' to them, but on the other hand, it calls strictly for firms to disclose all relevant and material information related to non-GAAP financial measures. 
Unfortunately, the guidelines may not have been effective enough to deter firms from using potentially misleading non-GAAP financial measures, as users of the financial measures have raised concerns around consistency and transparency with respect to the measures' calculation and presentation. In a commentary released by Royce Funds (Royce, 2016), analysts share that, "recently, we have observed a disturbing trend creeping more and more frequently into income statements and the growing gap between GAAP versus non-GAAP practices. This disturbing trend, a practice we call, earnings before bad stuff (EBBS) entails consigning items off the income statement by declaring them 'non-recurring' in order to burnish earnings". Similar concerns are voiced in a report issued by Veritas Investment Research (Veritas, 2016), who examine the regulation of non-GAAP financial measures and conclude that non-GAAP financial measures impact valuation of stocks and could adversely impact investors if not disclosed honestly and transparently.

In response to comment letters and complaints it received on the disclosures provided by real estate firms, the CSA specifically reviewed real estate firms in 2018 to assess the quality of disclosures provided by them. As result of this review, the CSA found real estate issuers need to improve the quality of disclosures of non-GAAP financial measures and issued Staff Notice 52-329 (CSA, 2018a), to address these issues and to provide guidance around prominence, reconciliation and persistence of non-GAAP financial measures disclosed by firms in the real estate industry.

The CSA's view of the gravity of this issue is evident by the follow up draft policy recently issued on non-GAAP financial measures in September 2018, namely the proposed National Instrument (NI) 52112, Non-GAAP and Other Financial Measures Disclosure (CSA, 2018c). The policy lays out disclosure requirements for firms that report non-GAAP financial measures and is expected to come into force in 2019. The main objective of this policy is to improve the quality of disclosures and to curtail self-serving manipulation of non-GAAP financial measures. Once in effect, NI 52-112 would replace the current CSA Staff Notice 52-306 (Revised) and is expected to have the desired efficacy and enforceability. NI 52-112 applies to all forms of communications, including the MD\&A, press releases, websites, and social media. It encompasses the non-GAAP financial measures, non-GAAP ratios, future financial outlooks and segment measures. The proposed disclosure requirements in NI 52-112 are summarized in Table 1 below. 


\section{TABLE 1: CSA NATIONAL INSTRUMENT 52-112 DISCLOSURE REQUIREMENTS (SOURCE: CSA, 2018C)}

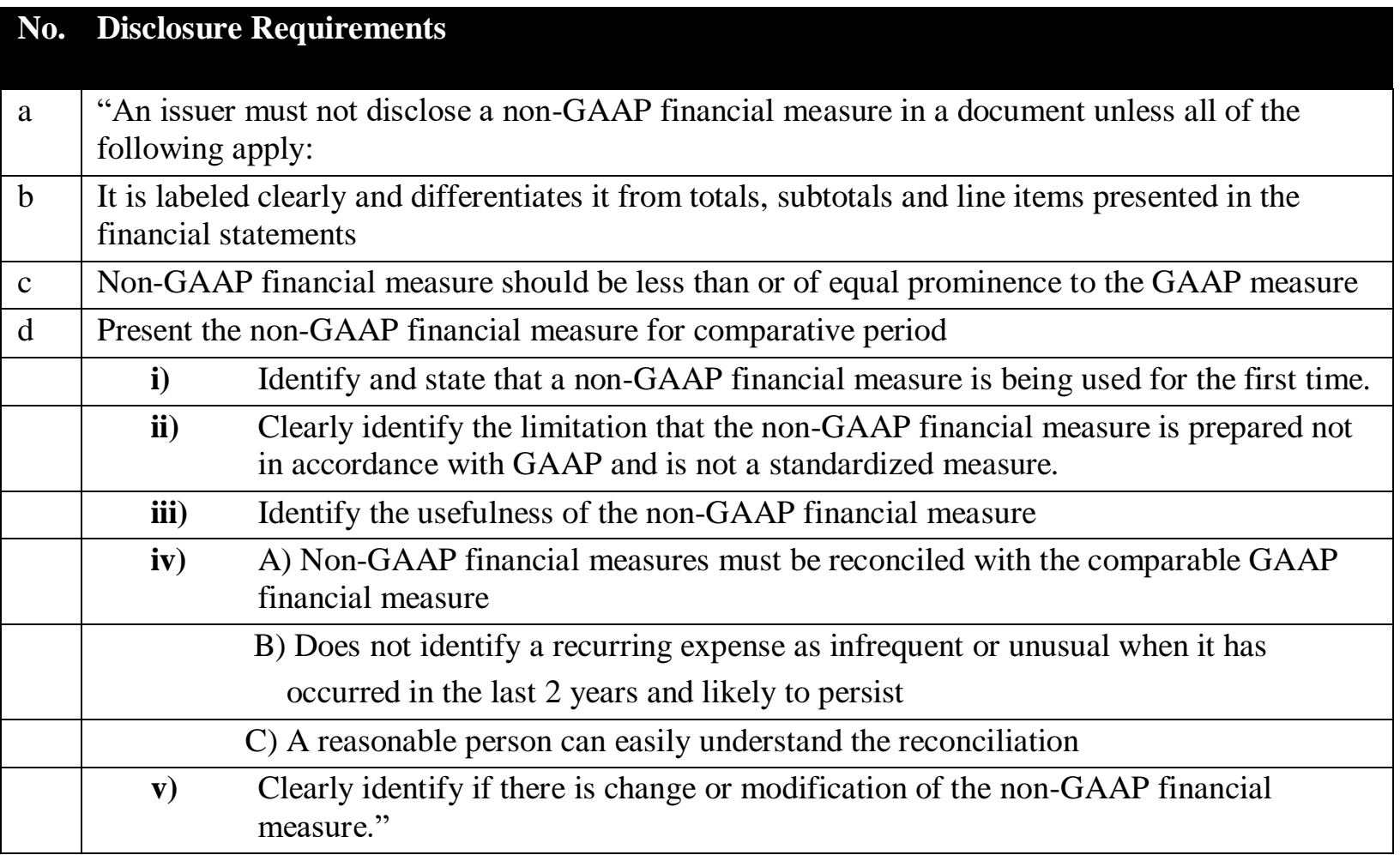

Although majority of the expected disclosure requirements in N1 52-112 are the same as the predecessor Staff Notice 52-306, greater emphasis is made on the understandability of each item by an average user. Also, the new policy undertakes to define clearly what a non-GAAP ratio is and how is it to be disclosed using the guidance provided in NI 52-112. It is worth reiterating here that a National Instrument, once implemented, is an enforceable regulation for publicly listed companies in Canada.

Alongside the CSA, the International Accounting Standards Board (IASB) expressed similar interest in performance measures through their disclosure initiative (IASB, 2014) whereby they attempt to provide a framework for firms making a material judgment when disclosing additional information. Likewise, to take a stronger position on non-GAAP financial measures, based on research and informed by professionals, the Canadian accounting standard setter, AcSB, issued its draft framework for reporting performance measures in June 2018 (AcSB, 2018a). This framework provides a list of 15 disclosure 
considerations for a firm to consider when reporting non-standardized performance measures. There is a significant overlap with NI 52-112 which delineates the main areas of concern in non-GAAP reporting.

The AcSB's framework has been developed in line with GAAP's conceptual framework of accounting, including the qualitative characteristics of decision-useful information: relevance, reliability, comparability, understandability, timeliness, consistency and verifiability. The scope of the AcSB draft guideline is not just limited to non-GAAP financial measures. It includes segment measures, capital management measures, supplementary financial measures, and future outlook measures. However, given the focus for this research is on non-GAAP financial measures, the study considers the guidelines related to this type of measure only.

In a recent letter issued by the AcSB to the CSA, it recognizes the need to for both institutions to support each other in meeting the common objective of improved information content (AcSB, 2018b). The mandate for both the proposed NI 52-112 and AcSB guidelines is to provide information necessary for the efficient allocation of capital and well functioning efficient capital markets (Cooper, 1984). It will be interesting to see the direction that the AcSB framework and the CSA policy take in the months to follow. Unlike the NI 52-112, the AcSB's draft framework is a guideline and not an enforceable regulation. Given the common purpose and similarities of the both sets of guidance, however, incorporation of the AcSB material into the CSA regulation, by reference, may possibly serve as a link to developing assurance guidance for professional accountants and auditors. This may be a route towards enhancing enforceability of the CSA regulation, since it would help to deter misleading reporting practices if independent assurance could be provided on these performance measures. Thus, a natural progression of the NI 52-112 and AcSB guidelines would be to develop standards for auditing non-GAAP financial measures, and for regulators to start to require that non-GAAP financial disclosures be audited. The AcSB draft guidelines, along with the CSA proposed policy, both outline best practices for informative reporting of non-GAAP financial measures, and so have been used the basis of the disclosure quality evaluation I perform in this study, as will be discussed further in the methodology section of this paper. 
This section has outlined the institutional background of the growth in corporate reporting of nonGAAP financial measures and related regulatory responses. The time line in Figure 1 below summarizes the evolution of regulations and guidance on non-GAAP financial measures that have been issued by the SEC, CSA and the AcSB. The discussion provides a strong institutional backing for my motivation to undertake this research. It is not only a novel area of research in Canada but given the expected changes in the reporting and regulatory environment, this study will support further research and identify areas to research in future.

FIGURE 1: TIMELINE OF REGULATIONS AND GUIDANCE ISSUED FOR NON-GAAP FINANCIAL MEASURES

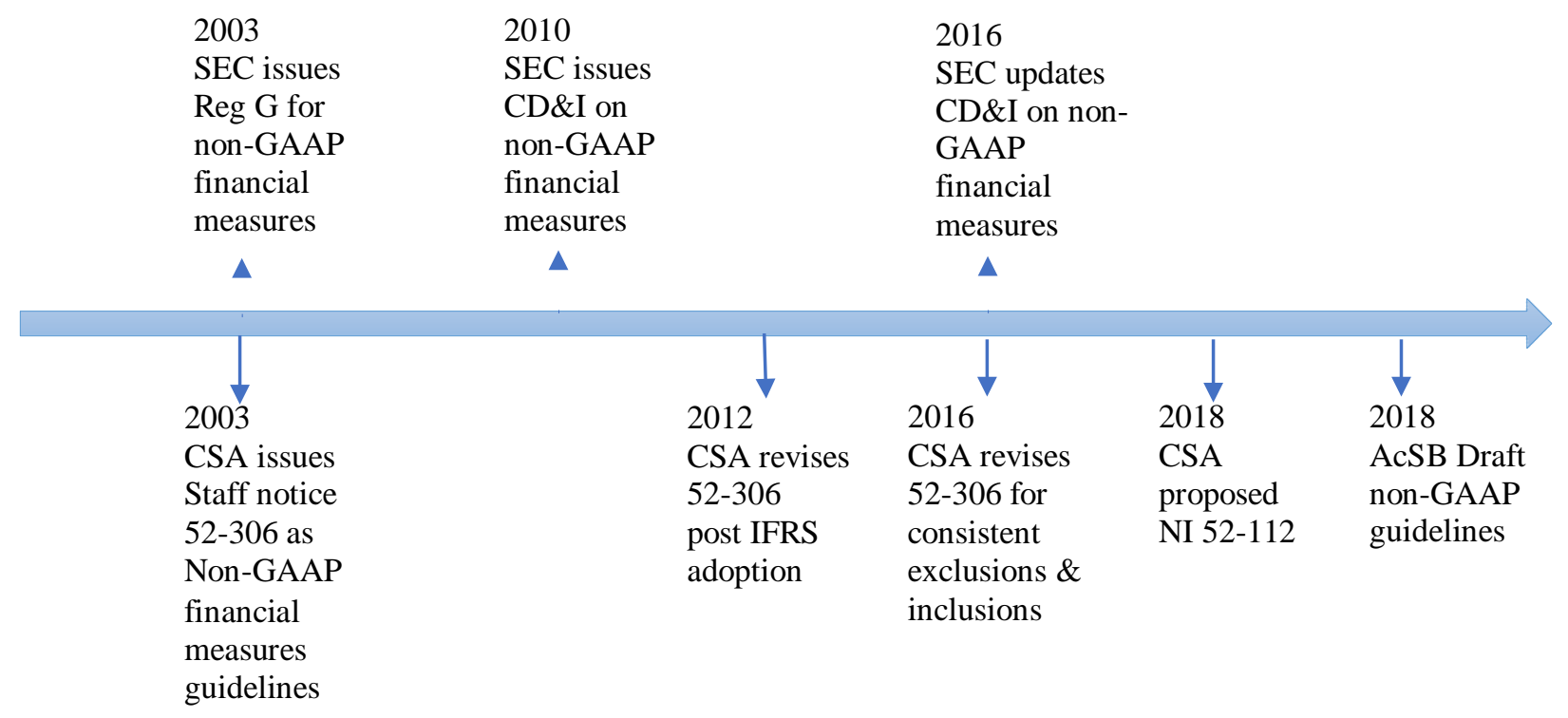




\section{Literature REVIEW AND RESEARCH QUESTIONS}

Reporting and disclosing of non-GAAP financial measures has increased noticeably across industries over the last decade. As examined and documented by Black \& Christensen (2009, 2017a), there has been a $34 \%$ increase in reported non-GAAP financial measures in S\&P 500 firms over the span of five years from 2009 to 2014, highlighting the increased acceptance, use, and reliance on the non-GAAP financial measures by users and stakeholders. This has raised concerns from various stakeholders regarding the impact of, and motivations behind, non-GAAP financial measures. There are growing concerns about the motivations guiding firms' disclosure of non-GAAP financial measures, which are not observable to users and which could be either informative or manipulative (Black \& Christensen, 2009). Hence, standard setters, regulators and academics are revisiting non-GAAP reporting with renewed interest. This section examines the research literature in the area of non-GAAP financial measures, identifies areas of potential further research, and forms the basis of my research questions.

If we look back into time, non-GAAP financial measures have been around for a considerable time, with research on the topic dating back to the 1970's when Adkerson (1978) discussed the need for alternative accounting measures which are more useful to an average user. Subsequent studies indicated that while the practice of disclosing non-GAAP numbers was still in its nascent stages, most researchers, press, and regulators were critical and skeptical about the phenomenon since the disclosure of non-GAAP earnings is a form of voluntary disclosure (Hitz, 2010; Isidro \& Marques, 2013). Theories on voluntary disclosure presents two alternative explanations behind the motivation of these disclosures, opportunism or informativeness (Dye, 1985). Dye (1985) states that there are motivations to both share information opportunistically and informatively and that the amount of information shared can differ depending on the proprietary nature of information, information asymmetry and principal agent problems.

Some studies suggest that non-GAAP measures could be used opportunistically in different ways to disguise and manipulate financial information about the firm. For example, Doyle et al. (2013) find that firms disclose non-GAAP financial measures after they have exhausted all possibilities to meet or beat benchmarks. The authors note that this result is somewhat puzzling, however, since non-GAAP disclosure 
is relatively lower cost compared to other earnings management techniques, which have real costs. So, one would think these firms would use non-GAAP financial measures before exhausting other costlier earning management techniques. Hence, the Doyle et al. (2013) study offers an area to further examine and investigate. Another example of opportunism is the use of non-GAAP earnings to beef up executive compensation (Isidro and Marques, 2013). These authors find that most of the executive compensation packages have been tied to non-GAAP measures on the pretext that these measures are easier to adjust for recurring items to increase management payouts. Thus, there are obvious incentives to support upward adjustments and exclusions to GAAP numbers. Guest et al. (2018) find that compensation committees assess managers based on non-GAAP financial measures. Most importantly, non-GAAP earnings have been observed to be used under market pressure, to make weak earnings look better in an attempt to meet or beat expectations (Graham et al., 2005).

Simultaneously, in contrast to this opportunistic view, the informative explanation for voluntary disclosure emerges in the literature suggesting that disclosures reduce the 'lemons' or agency problems by distinguishing high type versus low type firms (Jensen \& Meckling, 1976; Akerlof, 1970). Thus, nonGAAP financial measures can be informative rather than opportunistic. Furthermore, non-GAAP earnings have been observed to be useful to investors (Coulton et al., 2016), since they are more persistent than GAAP earnings (Bhattacharya et al., 2003) and more useful for valuation purposes (Bradshaw \& Sloan, 2002; Brown \& Sivakumar, 2003; Frankel \& Roychowdhury, 2005). Non-GAAP financial measures are perceived by outsiders to be from the eyes of managers, who have first hand information about the sustained operations and future profitability of the firm. Managers argue that they present measures that accurately capture firms' core earnings. Healy and Palepu (2001) provide a range of informative motivations for voluntary disclosure including improving share price, protecting the firm from takeovers, increasing managerial remuneration and promoting managers' reputations, relating to managing perceptions about the firms and its managers. 
Further to this perspective is the notion that the market is efficient and can see through any disguised information. This view implies there is little rationale for managers to abuse non-GAAP earnings to their own or the firm's benefit because if and when the market discovers the misrepresentation, the firm will be penalized with lower stock prices and higher cost of capital (Daske, 2006). A study in this context is done by Choi and Young (2015) where they examine a cross-section of firms in the UK to see the association between non-core, or transitory, earnings and non-GAAP earnings. Their main claim is that non-GAAP earnings could be used both opportunistically and informatively. The authors report evidence of a significant asymmetric relation between the propensity to disclose and transitory items in GAAP earnings, and this association is conditional on the sign and magnitude of the GAAP earnings surprise. Their findings suggest that managers are motivated to make non-GAAP earnings disclosures for informative reasons when GAAP earnings exceed market expectations, but the disclosure choice appears to be strategic, so possibly to manage impressions, when GAAP earnings are less than expected. The authors conclude that, ultimately, it is the intention behind reporting such measures as non-GAAP earnings that makes it useful or otherwise.

Combining the findings and evidence of informative and opportunistic motivations for disclosing non-GAAP financial measures, Wang (2014) provides a different explanation for the behaviors of managers and the potential response of the market participants with respect to non-GAAP financial measures. His study shows that the response from the market is varied given how much knowledge the investors have, what the economic conditions are, and what penalties are in place for misreporting. The findings support the claim that if the market is transparent, investors have bargaining power, and if the regulators have the power to enforce regulations and levy penalties, then the manipulation of non-GAAP earnings is lower than if these factors are missing. The empirical evidence they find is based on the US market from 2003 to 2010. They take into consideration the financial crisis of 2008 in their data and analysis. This time frame chosen is of particular interest also because not only does it explain firms' behavior in times of crisis but also the response to Regulation G that was introduced in the US in 2003. My study is related the findings in Wang 
(2014) as it assesses the quality of Canadian firms' of non-GAAP financial disclosures by comparing the adjustments firms are making to their GAAP information to detailed guidance from regulators.

To further understand non-GAAP financial measures, one must understand the users of this particular genre of information. This leads to the question, “who uses non-GAAP earnings?” Derby (2001) argued that investors do get the additional information through non-GAAP financial measures, but the numbers are misleading and opportunistic only for the benefit of the firm. But it was important to gauge investor response to these metrics for which Bradshaw and Sloan (2002) examined a significant sample of US-listed companies and found that investors react to non-GAAP numbers ('street earnings') more than they react to the GAAP earnings measures. Subsequent studies confirmed their findings, showing that investors believe adjustments made by managers are more relevant than GAAP numbers. Similar conclusions were drawn over the next decade by Johnson and Schwartz (2005) and Wieland et al. (2013). Further to Weiland et al. (2013) and Johnson and Schwarts (2005), through this study I examine the various and common adjustments made to non-GAAP financial measures to contribute insights to better understand the potential usefulness of non-GAAP financial measures.

Bhattacharya et al. (2007), through their archival study, claim that non-GAAP earnings appeal differently to different types of investors. They back this claim with the theory that the decision-making process is different among different users given their existing stock of knowledge. The evidence they find supports their claim and suggest that investors who are less sophisticated and knowledgeable rely more on non-GAAP earnings than analysts do. They perform a detailed analysis for the stock returns of firms listed on the US stock exchange. The possible reasons explaining this behavior is that analysts are trained to break down the GAAP earnings to find the core operating earnings of the firm for their analysis process. On the other hand, less sophisticated and naïve investors are not trained in doing such a manipulation of net reported income and hence rely on non-GAAP measures reported by the firm for insight to guide their decisionmaking. This is confirmed in other follow up studies as well by Alle et al. (2007) and Frederickson \& Miller (2004). 
Another set of studies empirically test and conclude that other stakeholders also use the non-GAAP financial measures. According to Bhattacharya et al. (2003), sell-side analysts use non-GAAP financial measures while revising forecasts they prepare. Another set of users, the credit analysts, use adjusted performance metrics (Batta \& Muslu, 2017). Lenders also assess the creditworthiness of the potential loan by incorporating non-GAAP information in their assessment and covenants. (Dyreng et al., 2017). Analysts find non-GAAP financial measures to be confirmatory when firms provide a reconciliation of the nonGAAP numbers with the audited GAAP numbers (Elliot, 2006), as this adds a layer of assurance. Analysts recognize the adjustments made by firms to be a better representation of their sustained core operations and place more emphasis on these unaudited numbers in their forecasts. (Andersson \& Hellman, 2007).

Not only it is the users of non-GAAP financial measures that can vary, there are also multiple uses of non-GAAP information observed. Compensation packages have been linked to non-GAAP numbers as a basis for bonuses for executives of S\&P 500 companies. (Curtis et al., 2017). Research found evidence suggesting that debt contracts are developed by including positive and negative covenants based on nonGAAP financial measures and if the conditions of the contract are breached, then management is discouraged from releasing non-GAAP financial measures for fear of negative reaction from the market (Christensen, 2017b).

Given that the existing research has highlighted the negative implications of the non-GAAP disclosure there has been increased pressure on the regulators to prohibit non-GAAP disclosures. (Bond et al., 2017; Hoogervorst, 2015; Shumsky, 2016). With concerns around non-GAAP financial measures, the US regulators responded with strict rules to be adhered to when reporting non-GAAP financial measures by imposing Reg G and CD\&I.

Lee and Chu (2016) address the relationship between greater regulatory burden and discontinuation of non-GAAP disclosures. They claim that if non-GAAP earnings are heavily regulated, it will take away the ability of firms to signal their accurate performance. Either too much or too little regulation may both be detrimental to the firms, markets and market participants as a whole. They support their claim stating that if firms are unable to communicate their superior performance, investors are prone to make a bad 
investment decision since all firms appear to be the same. Bond et al. (2017) test the market response to Reg G and C\&DI and report polar findings. They report relevant and useful information being disclosed after Reg G, with fewer upward adjustments and improved earnings response coefficient (ERC), meeting its main objective of improving the quality of disclosure. Heflin and Hsu (2008) report that Reg G levied significant reporting, reconciliation and presentation requirements on firms making it costly for firms to continue reporting and disclosing non-GAAP financial measures. The authors find that some firms stopped reporting such measures in press releases. Also, firms were found to have further reduced their usage and reporting of non-GAAP financial measures after the introduction of the CD\&I regulation.

Kyung and Weintrop (2016) indicate that stakeholders perceive any regulatory intervention to have affected financial reporting. Managers are found to be more cautious in their use of non-GAAP financial measures and attempt to follow the given guidelines due to the risk of being reviewed for inconsistency. Related to the findings of Kyung and Weintrop (2016), my study examines the quality of non-GAAP financial disclosures by scoring the sample firms' disclosure in accordance with the guidance issued by the regulators. The impact of reporting regulation would also be an interesting issue to study further, in future research, by replicating the research design in Kyung and Weintrop (2016) in a Canadian setting after NI 52-112 has been implemented.

Kyung and Weintrop (2016) also find that the success of any guideline and intervention is dependent on the level of governance and internal controls the firms have. Companies with weak corporate governance are expected to use non-GAAP measures in a more aggressive manner than those with good governance. This expectation is further examined by Cormier et al. (2017) who conclude that firms use nonGAAP numbers to substitute for weak governance, in order to enable the market to better assess the firm. Specifically, these authors find that reporting EBITDA helps market participants to better assess valuation when a firm's governance is weak and, inversely, that releasing EBITDA information has a much smaller impact on the earnings-price relation when governance is strong. Frankel et al. (2011) suggest that nonGAAP earnings are of higher quality if the boards are independent. Isidro and Marques (2013) support this with evidence of a strong board of directors reducing aggressive non-GAAP reporting. 
In addition to explicit regulations, there are natural checks and balances in place against misuse of non-GAAP financial measures, which comes from the market participants. Litigation threat can act as a means to monitor and deter firms from opportunistic reporting of non-GAAP information (Cazier et al., 2017; Bentley et al., 2018). Other stakeholders, such as institutional investors, lenders and compensation committees, keep a close eye on non-GAAP financial measures when the contracts they write are prepared on the basis of these non-GAAP financial measures (Christensen et al., 2017b). More analyst following is considered to be an indicator of higher quality disclosure (Christensen et al., 2017a). The theory for this is further elaborated by Bentley et al. (2018) who find that analysts' attention to non-GAAP financial measures performs the same function as constant monitoring would and the quality of disclosure is better when the exclusions made by analysts and firms are similar. As further preliminary analysis in this study I test for association between analyst following and quality of non-GAAP disclosures, although due to sample limitations and related econometric issues these preliminary findings lack robustness and will require examination in future study designed to address the issues.

While a significant literature for non-GAAP measures comes from the US, evidence, results and conclusions presented by research in other parts of the world tend to corroborate the US-based literature. A study done in the UK, using an accounting-based valuation model, finds that firms resort to non-GAAP reporting more after a new accounting standard has been introduced (Lin and Walker, 2000). This is direct evidence that firms attempt to circumvent the excessive burden placed by traditional standards through nonGAAP disclosures. Beyond the US, customized financial measures are commonplace but with varying level of scrutiny. Isidro and Marques (2015) identify the varying level of regulations, restriction, and governance in different countries with respect to non-GAAP financial measures and identify the need to examine nonGAAP financial measures on national levels and to proceed with caution when generalizing the findings.

There have been two studies that investigate the use of non-GAAP financial measures by Canadian firms (Entwistle et al., 2005; Cormier et al., 2017). The main findings of Cormier et al. (2017) suggest that non-GAAP financial measures are more strongly associated with analysts following than with information asymmetry. They also report a positive relation between earnings and stock price, and posit that when a 
firm's governance is weak, EBITDA (a non-GAAP financial measure) acts a substitute for stakeholders. The study by Cormier et al. (2017) is geared towards understanding the response of market participants.

The second Canadian study is by Entwistle et al. (2005) in which they report more prominent and more frequent reporting of non-GAAP measures with more adjustments to the GAAP numbers in the US as compared to Canada. However, they also find that the impact of non-GAAP disclosures on the market and its participants are almost the same in US and Canada. The potential explanation offered is the similar market structure and institutional framework in Canada and US. However, since this study is a decade old and the reporting regimes and regulatory power in the two countries are different, it presents an area of further examination in future studies. Due to limited research on non-GAAP financial measures, regulators in Canada must rely on studies from other countries reporting non-GAAP financial measures to formulate guidelines on non-GAAP financial measures, which overlooks the institutional differences and raises external validity concerns. A major contribution of this study is that it will focus on Canada and explore the behavior of firms when reporting and disclosing non-GAAP financial measures. This gap in studies on nonGAAP financial measures in rest of the world has been identified by Marques (2017) by indicating that there is room to do more research in countries outside of the U.S. as well. Addressing this gap, my study examines the content of Canadian listed companies' non-GAAP financial disclosures, and assesses their quality based on the level of compliance with the guidance issued by the regulators.

With ever increasing use of non-GAAP measures, it is important to understand what adjustments and revisions are made to the GAAP earnings to make them more accurately reflect a firm's performance, and how different these non-GAAP financial measures are from the reported GAAP earnings. Initially, the practice was to only adjust non-recurring, extraordinary, and special items. (Entwistle et al., 2005). The gap between GAAP and non-GAAP numbers widened in the 1980s and 1990s due to use of multiple other types of adjustments (Bradshaw and Sloan, 2002). Managers exclusions moved beyond transitory to more 'pick-and-choose' adjustments, with taxes, restructuring and acquisition costs being the common choices. (Curtis et al., 2013; Donelson et al., 2018). Similar findings were reported, 
supported by empirical evidence, by Bradshaw and Sloan (2002) and Bhattacharya et al. (2003) with respect to non-cash adjustments like amortization and depreciation.

One of the reasons pushing firms to make adjustments to GAAP earnings is the accounting standards and the level of conservatism that is expected to be exercised, compelling firms to include a certain item in the GAAP measures being reported (Barth et al., 2012). Non-GAAP earnings disclosure and their value relevance have been extensively examined in depth by Venter (2014), who reports a higher relevance of non-GAAP numbers as compared with GAAP numbers, and that different firms exclude different expense and revenue items to arrive at the non-GAAP earnings. While noting that there are no models to assess which firm could deploy which method of exclusion, the study does point out some common practices across industries and countries, and supports the claim that the non-uniform practices in non-GAAP financial measures is a result of freedom to define relevant expense or earnings from a firms' perspective. However, not many prior studies specifically examine current practice in various industry groups when reporting non-GAAP financial measures, which is a gap that my study aims to fill.

\section{Development of Research Questions}

Based on the above review of existing literature on non-GAAP financial measures, I have identified gaps that that my research can to contribute to filling. To further our understanding of the use of non-GAAP financial measures in Canada, following Entwhistle et al. (2005), I examine in detail and document common non-GAAP financial measures reported by publicly listed Canadian firms in their MD\&A. Through analysing the content of these measures, I describe the exclusions and inclusions firms make in defining these measures. To add to the previous studies, my study compares the reporting across industry groups that the Canadian regulators identify as high risk or emerging sectors and have expressed particular concerns about. By examining how firms' non-GAAP financial disclosures conform to best practices guidance from regulators, my study provides further evidence related to the findings of Wang (2014) and Cormier et al. (2017). Building on Kyung and Weintrop (2016), I examine the quality of non-GAAP financial disclosures by scoring the sample firms' disclosure in accordance with the guidance issued by the regulators. I measure disclosure quality by reviewing the details of guidance proposals recently issued by 
the two Canadian regulators, the CSA and AcSB (CSA, 2018c; AcSB, 2018a)' and developing a checklist based on these guideline that I use to measure non-GAAP financial disclosure quality.

In summary, the main goals of my study are exploratory and aim to address the gaps in existing literature by examining the behavior of Canadian firms when choosing to report non-GAAP financial measures, by describing firms' current practices in defining and computing non-GAAP financial measures, by comparing non-GAAP reporting practices firms in emerging and high-risk industry groups, and by evaluating the quality of Canadian firms' current non-GAAP financial measures against guidance provided by Canadian regulators. Based on these exploratory research goals, the research questions developed for the study are stated as follows:

For a sample of Canadian publicly listed firms drawn from three sectors that are characterized as being high risk or emerging industry groups:

RQ1: What are the various and common non-GAAP financial measures that the sample firms choose to disclose in their 2017 MD\&As across the three industry groups?

RQ2: What common adjustments do the sample firms make to compute the reported non-GAAP financial measures?

RQ3: What is the quality of non-GAAP financial disclosures as assessed by their compliance with the Canadian regulators' proposed disclosure guidelines?

This study is primarily descriptive in nature to qualitatively analyze current practices in calculating, reporting and disclosing non-GAAP financial measures. A detailed content analysis will be undertaken for the purpose of addressing RQ1 and RQ2. To address RQ3, I will use the guidelines issued by the CSA and AcSB to develop a comprehensive checklist of parameters that indicate good reporting practices and analyze the extent to which the firms comply with each of these parameters. The checklist is also used to score each firm's non-GAAP financial disclosures by assigning a score of "0" for non-compliance and a score of "1" for compliance. The individual score is cumulatively called disclosure score for each firm, where a higher score means higher quality disclosure. A major contribution of this study is that it focusses 
on Canadian firms and explores their behavior when reporting and disclosing non-GAAP financial measures, and also examines the developing best practices guidance that regulators are issuing in Canada to try to enhance the quality of non-GAAP financial measures reporting. 


\section{DAta AND Methodology}

To address the research questions and contribute to understanding non-GAAP financial reporting by Canadian listed companies, the population of 3,092 firms listed on the Toronto Stock Exchange (TSX) and Toronto Ventures Exchange (TSXV) for the year 2017 was used for sample selection. A detailed listing of firms was obtained from the Toronto Montreal Exchange (TMX Group) website ${ }^{3}$, which outlines company information, tickers, number of outstanding shares, market valuation in Canadian dollars, industry sectors and sub-sectors, and other listing data.

Given the exploratory nature of this study and the fact that my research question aims to gain an industry level understanding on non-GAAP financial measures, firms from three industry groups, Real Estate, Blockchain/Cryptocurrency, and Cannabis ${ }^{4}$ are selected for analysis. I determined that these three industry groups are most relevant for my study because they have been identified and highlighted by the CSA, in CSA Staff Notice 51-355 issued as part of its continuous disclosure review program (CSA, 2018b), as highrisk and emerging industries with potential issues related to firms' non-GAAP disclosure practices. Real estate firms are of particular interest due to their recent review by the CSA, whereby the CSA identified issues and provided guidance to improve the quality of disclosures of non-GAAP financial measures. as outlined in Staff Notice 52-329, Distribution Disclosures and Non-GAAP Financial Measures in the Real Estate Industry (CSA, 2018a). Furthermore, the CSA reviewed cannabis firms and issued Staff Notice 51357, Staff Review of Reporting Issuers in the Cannabis Industry and identified non-GAAP disclosure practices among the firms that are vulnerable to comparability issues (CSA, 2018c). Firms in the blockchain/cryptocurrency industry have also been identified in Staff Notice 51-355 as an emerging industry, since they are similar to cannabis firms with respect to their evolution. Firms from these three industry groups a the focus of the study because they are expected to provide non-GAAP financial

\footnotetext{
${ }^{3}$ https://www.tsx.com/listings/

${ }^{4}$ The industry group definitions used in this study are based on TSX sector and sub-sector classifications that most closely align with the CSA's industry identifiers and may be categorized differently. Note that these industry group definitions may not be comparable to other studies that use Global Industry Classification System (GICS) or (North American Industry Classification system (NAICS) industry classifiers or any other method.
} 
measures, they appear likely to exhibit a variety of practices that are important to examine to address the study's purpose of advancing our understanding of the current state of non-GAAP financial measures reporting in Canada, and in light of the developing regulatory guidance around the quality of this type of corporate disclosure which motivates this study.

From the population of 3,092 TSX listed companies, I used the TSX sector and sub-sector definitions to identify firms that operate primarily in the three industry groups of interest. ${ }^{5}$ Based on this selection approach, 91 Real Estate firms, 29 Blockchain/Cryptocurrency firms and 47 Cannabis firms were identified. Of these firms, I selected the 25 firms with the highest market capitalization potential companies from each of the selected industry groups for inclusion in the study. This sampling approach was designed to provide a variety of observations of firms' non-GAAP reporting practices, while maintaining a reasonable scope for the research design of this master's thesis, which involves intensive hand collection and coding of data. The list of 75 firms selected by this process is reported in Appendix C, along with the industry group and market capitalization information that I used as selection criteria.

For the descriptive analysis and disclosure quality assessment, data for the sample firms have been collected from two main sources, the MD\&As and the financial statements for the years 2016 and 2017. These documents were downloaded from SEDAR. After accounting for missing MD\&A for one firm in the Real Estate industry group, the sample was left with a total of 74 companies for study. The MD\&As for the 74 sample firms were downloaded from SEDAR for the year 2017 and 2016 yielding 148 firm-year observations. These MD\&As were examined to identify the presence of non-GAAP financial measures disclosures. The year used for my main analysis is 2017 , since the latest revised guidance on non-GAAP financial measures was issued in 2016 (CSA, 2016), so the year 2017 is the first year it is in effect and prior years would not be relevant. To assess the quality of disclosure with respect to consistency in the firms'

\footnotetext{
${ }^{5}$ Real Estate industry group comprises of operating companies dealing with Industrial/office/retail/residential property lease and operations. Cannabis industry group operates primarily in the Life Sciences sector to cultivate and produce medical and recreational marijuana. Blockchain/Cryptocurrency industry group, belong to the Technology sector, includes firms which are record keeping technology firms or with tradable digital asset.
} 
year-on-year reporting of non-GAAP financial measures and exclusions, reports for 2016 were also examined.

The data for this study were hand collected from the MD\&A of each firm. There are some databases like COMPUSTAT and I/B/E/S which could have been used to extract data on the reported non-GAAP financial measures, but the level of detail and insight needed for this study would not be available. The study's analysis is exploratory and descriptive in nature, which is best performed by hand collecting the data. Furthermore, there is evidence that for most non-GAAP studies, hand collecting data is more accurate and insightful than using existing databases since it provides the researcher with a closer perspective on each individual manager's approach to making inclusions and exclusions (Bentley et al., 2018).

To begin, I read each MD\&A in detail to identify firms that are reporting non-GAAP financial measures and those that are not. There are 43 of the 74 firms who choose to disclose non-GAAP financial measures, and the remainder do not ${ }^{6}$. The sample selection results are summarized by industry group and in total in Table 2. This was followed by collecting data on the non-GAAP financial measures disclosed by each disclosing firm and the adjustments made by the firm to GAAP numbers when they calculate and report the non-GAAP financial number. This exercise is useful to understanding of firms' current practices in reporting non-GAAP financial measures among firms and across the industry groups. During the process of data collection, specific attention was paid to identify individual non-GAAP financial measures and to analyze them to their core. Again, the focus was on non-GAAP financial measures, so any non-GAAP nonfinancial measures, also referred to as 'Key Performance Indicators' (KPIs), were excluded. Additional data related to firms' GAAP measures were taken from the financial statements rather than the MD\&A for greater reliability since the MD\&A is not audited.

Simultaneously, based on the MD\&A and the information therein, non-GAAP financial disclosures are scored across 24 parameters to assess the quality of disclosure against a checklist. Similar to Clarkson et al. (1999), where analysts have been asked to score the MD\&A for its value relevance, I use a checklist

\footnotetext{
${ }^{6}$ The discloser and non-discloser firms in the sample are reported in the sample listing in Appendix C.
} 
developed using the authoritative CSA (CSA, 2016; 2018c) and AcSB (AcSB, 2018a) guidelines to score the firms' non-GAAP financial disclosure quality across the 24 parameters. There have been quite a few studies that use some form of scoring or index method like the one I use to score disclosure quality, for example, Mohanram (2005), and my study adopts a similar approach. A score of ' 1 ' is given when the firm meets the specific disclosure criteria as per the guidelines and ' 0 ' is given for non-compliance with the guidelines. There were no cases where the firms partially met the requirement since the checklist is designed with specific focus on each parameter and it is either adhered to or otherwise. To further mitigate biased scoring, the name of each sample firm was also coded. Additionally, interrater reliability was assessed by having two suitably qualified independent scorers ${ }^{7}$ perform the scoring for 15 randomly selected MD\&As from the full sample of 74 firms, yielding a rank correlation of 0.88 and 0.85 with my own scoring, as further discussed in the results section.

TABLE 2: SAMPLE SELECTION

\begin{tabular}{|l|l|l|l|l|}
\hline \multicolumn{2}{|c|}{$\begin{array}{l}\text { Real } \\
\text { Estate }\end{array}$} & Cannabis & \multicolumn{1}{c|}{$\begin{array}{l}\text { Blockchain/ } \\
\text { Crypto- } \\
\text { currency }\end{array}$} \\
\hline Population of TSX listed companies in the industry groups & 91 & 47 & 29 & 163 \\
\hline Sample of largest firms selected for study & 25 & 25 & 25 & 75 \\
\hline Firm lost due to missing MD\&A & $(1)$ & 0 & 0 & $(1)$ \\
\hline $\begin{array}{l}\text { Sample available for analysis of non-GAAP financial } \\
\text { measures }\end{array}$ & $\mathbf{2 4}$ & $\mathbf{2 5}$ & $\mathbf{2 5}$ & $\mathbf{7 4}$ \\
\hline Firms disclosing Non-GAAP financial measures & 24 & 10 & 9 & 43 \\
\hline Firms not disclosing Non-GAAP financial measures & 0 & 15 & 16 & 31 \\
\hline
\end{tabular}

\footnotetext{
${ }^{7}$ Rater 1 qualifications and current position: MBA, CFA. DBS Bank Ltd, Singapore

Rater 2 qualifications and current position: FCA, Hyder \& Co Chartered Accountant, Pakistan
} 


\section{DESCRIPTIVE ANALYSIS OF MD\&A}

This section is divided into two sub-sections. The first sub-section examines the use and adjustment of nonGAAP financial measures, whereas the second sub-section discusses the quality of non-GAAP disclosures based on disclosure scoring

\section{USE OF NON-GAAP FINANCIAL MEASURES AND ADJUSTMENT ANALYSIS}

This sub-section section seeks to address research question one and establish what the various and common non-GAAP financial measures are that the sample of Canadian firms choose to disclose among different industry groups. Furthermore, this section also examines the common adjustments made by the sample firms to compute non-GAAP financial measures across various industry groups and to gain insights into the second research question.

As shown in Table 2, based on carefully examining and tabulating the results from the MD\&A of firms, I find that from the total sample of 74 firms, 31(42\%) do not report any non-GAAP financial measure and the remaining 43(58\%) disclosed non-GAAP financial measures. The 43 discloser firms are comprised of $24(100 \%)$ of the sample of Real Estate firms, 10(40\%) of the Cannabis firms and $9(36 \%)$ of the Blockchain/Cryptocurrency firms.

My content analysis of the 43 disclosing firms' MD\&A shows that these firms report 74 different non-GAAP measures. These 74 measures are reported in Appendix A. With a minimum of one non-GAAP measure reported and a maximum of 13 measures on a per firm basis, this points out the proliferation and variability in reporting non-GAAP financial measures that could potentially create or contribute to confusion among financial statements users. One potential explanation for this wide variability in the use of reported non-GAAP financial measures could be the lack of guidance and standardization with respect to non-GAAP financial measures. Alternatively, firms might be disclosing non-GAAP financial measures to keep up with other firms in their industry. Further studies are warranted in this area to examine managers' behavior. 
The data from the discloser sample further show that most of the non-GAAP financial measures are disclosed by firms in the Real Estate industry group. This potentially is because real estate firms often have complex and unique operations and contracting arrangements which require them to disclose additional financial information, such as operating cash flows and funds from operations. In addition, this industry is well established with a history of providing industry specific financial data, as compared to the emerging industry groups included in my sample. A real estate industry support group, REALpac, publishes handbooks that provide firms with recommended financial reporting practices. For example, Whitepaper (REALpac, 2017) was first issued in 2003, with subsequent revision to date, and provides guidance on reporting measures that are common to real estate firms in accordance with IFRS and Accounting Standards for Private Enterprises (ASPE).

Table 3 reports results from my analysis of the 74 most commonly reported non-GAAP financial measures by the 43 discloser firms, including how many of the sample firms disclose each type, and their percentages in total and by industry group. Table 3 provides details about selected reported measures, including two measures that are reported by all three industry groups, and two reported measures that are unique in each of the three groups to show the types of unique measures observed across industries. The two measures that are reported in all industry groups are Adjusted EBITDA and Free Cash Flows (28 and 6 of the 43 companies report these, respectively). In each industry group, the Real Estate firms report Funds from Operations and Net Operating Income (by 22 and 17 of the 24 firms, respectively), the Cannabis firms report Cash Cost to Produce and Adjusted Product Contribution (by 3 and 4 of the 10 firms, respectively) and the Blockchain/Cryptocurrency firms report Return on Invested Capital and Research \& Development Expense (by 2 and 1 of the 9 firms, respectively). 


\section{TABLE 3: SELECTED FREQUENCIES OF NON-GAAP FINANCIAL MEASURES WITH INDUSTRY BREAKDOWN}

\begin{tabular}{|c|c|c|c|c|c|}
\hline & $\begin{array}{l}\text { Reported non-GAAP financial } \\
\text { measure }\end{array}$ & $\begin{array}{l}\text { Real } \\
\text { Estate } \\
(24 \\
\text { Firms })\end{array}$ & $\begin{array}{l}\text { Cannabis } \\
\text { (10 } \\
\text { Firms) }\end{array}$ & $\begin{array}{l}\text { Blockchain } \\
\text { /Crypto } \\
\text { (9 Firms) }\end{array}$ & $\begin{array}{l}\text { Total of } \\
\text { the } 43 \\
\text { Discloser } \\
\text { Firms }\end{array}$ \\
\hline 1 & Adjusted EBITDA & $13(54 \%)$ & $7(70 \%)$ & $8(89 \%)$ & 28 \\
\hline 2 & Free Cash Flows & $4(17 \%)$ & $1(10 \%)$ & $1(11 \%)$ & 6 \\
\hline 3 & Funds from Operations & $22(83 \%)$ & - & - & 22 \\
\hline 4 & Net Operating Income & $17(24 \%)$ & - & - & 17 \\
\hline 5 & Cash Cost to Produce & - & $3(30 \%)$ & - & 3 \\
\hline 6 & Adjusted Product Contribution & - & $4(40 \%)$ & - & 4 \\
\hline 7 & Return on Invested Capital & - & - & $2(22 \%)$ & 2 \\
\hline 8 & Research and Development Expense & - & - & $1(11 \%)$ & 1 \\
\hline
\end{tabular}

As shown in Table 3, the most common non-GAAP financial measure is adjusted earnings before interest, tax, depreciation and amortization (Adjusted EBITDA) which adjusts the GAAP earnings to exclude these expenses, to try to present a measure of the core operating earnings for a firm. Adjusted EBITDA is disclosed by 28 sample firms, which is $65 \%$ of the entire sample of 43 discloser firms. At the industry group level, 13 out of the 24 Real Estate firms (54\%), eight out of the $10(80 \%)$ of the Blockchain/Cryptocurrency firms, and seven out of the nine (78\%) Cannabis firms report EBITDA as a non-GAAP financial measure.

For each of the non-GAAP financial measures reported by a firm, it calculates the measure by making certain inclusions and exclusions. Based on further analysis of the reported non-GAAP financial measures reported in my sample, I observe that single reported measure is the result of numerous adjustments made to the GAAP financial measures. The number of adjustments firms might make to a GAAP number to produce a non-GAAP financial measure ranges from two adjustments to as many as 14 adjustments. As a detailed example, Table 4 reflects the distribution of the 14 adjustments that can be made to arrive at adjusted EBITDA, which is the most commonly reported non-GAAP financial measure observed in my sample firms across all three industry groups. While a majority of firms adjust for the main expenses 
included in the name of the measure (i.e., depreciation and amortization, interest and tax), a variety of other adjustments are also observed that are less clearly linked to measuring the core operation earnings of the firm. Since adjusted EBITDA appears to be a popular non-GAAP financial measure that reported by a majority of sample firms across all the industry groups, this indicates a lack of consistency among firms when making adjustments to report the non-GAAP financial measure. The variations may very well be attributed to the nature of their operations and industry factors, but this could ultimately make the financial measures lack comparability and usefulness. Further details of the adjustments observed to be made to he other common non-GAAP financial measures are reported in Appendix B

\section{TABLE 4: ANALYSIS OF TYPES OF ADJUSTMENTS USED TO COMPUTE ADJUSTED EBITDA}

\begin{tabular}{|c|c|c|c|c|c|}
\hline \multirow{2}{*}{\multicolumn{2}{|c|}{ Adjustments to Adjusted EBITDA }} & \multicolumn{4}{|c|}{ Industry Group Breakdown } \\
\hline & & $\begin{array}{l}\text { Real } \\
\text { Estate } \\
\text { (Total 13) }\end{array}$ & $\begin{array}{l}\text { Cannabis } \\
\text { (Total 7) }\end{array}$ & $\begin{array}{l}\text { Blockchain } \\
\text { / Crypto } \\
\text { (Total 8) }\end{array}$ & $\begin{array}{l}\text { No. of } \\
\text { Companies } \\
\text { Adjusting } \\
\text { (Total 28) }\end{array}$ \\
\hline 1 & Depreciation and Amortization & $10(77 \%)$ & $7(100 \%)$ & $6(75 \%)$ & 23 \\
\hline 2 & Adjustment for Interest Expense & $9(69 \%)$ & $5(71 \%)$ & $7(88 \%)$ & 21 \\
\hline 3 & Tax adjustment & $7(54 \%)$ & $4(57 \%)$ & $6(75 \%)$ & 17 \\
\hline 4 & Share-based payment & $2(15 \%)$ & $6(86 \%)$ & $4(50 \%)$ & 12 \\
\hline 5 & Adjustment to FV of Financial Instruments & $7(54 \%)$ & $3(43 \%)$ & $1(13 \%)$ & 11 \\
\hline 6 & $\begin{array}{l}\text { Adjustment to FV of Biological Assets / } \\
\text { Inventory }\end{array}$ & - & $6(86 \%)$ & $1(13 \%)$ & 7 \\
\hline 7 & Adjustment to FV of Investment Properties & $6(46 \%)$ & - & $1(13 \%)$ & 7 \\
\hline 8 & Non-Recurring Expense & $5(38 \%)$ & $1(14 \%)$ & $1(13 \%)$ & 7 \\
\hline 9 & Gain/Loss on Equity accounted Investee & $3(23 \%)$ & $1(14 \%)$ & $1(13 \%)$ & 5 \\
\hline 10 & Non-Cash Interest Expense & $1(8 \%)$ & $2(29 \%)$ & - & - \\
\hline 11 & FV adjustment to Cost of Sales & - & $2(29 \%)$ & - & - \\
\hline 12 & Listing Expense & - & $2(29 \%)$ & - & - \\
\hline 13 & Incremental Leasing Cost & $2(15 \%)$ & - & - & - \\
\hline 14 & Acquisition Cost / Integration Cost & - & - & $2(25 \%)$ & - \\
\hline
\end{tabular}


TABLE 5: ANALYSIS OF TYPES OF ADJUSTMENTS USED TO COMPUTE FREE CASH FLOWS (FCF)

\begin{tabular}{|c|c|c|c|c|c|}
\hline & \multirow[t]{2}{*}{ Adjustments to Free Cash Flows } & \multicolumn{4}{|c|}{ Industry Group Breakdown } \\
\hline & & $\begin{array}{l}\text { Real } \\
\text { Estate } \\
\text { (Total 4) }\end{array}$ & $\begin{array}{l}\text { Cannabis } \\
\text { (Total 1) }\end{array}$ & $\begin{array}{l}\text { Blockchain } \\
\text { / Crypto } \\
\text { (Total 1) }\end{array}$ & $\begin{array}{l}\text { No. of } \\
\text { Companies } \\
\text { Adjusting } \\
\text { (Total 6) }\end{array}$ \\
\hline 1 & Capex & $4(100 \%)$ & - & $1(100 \%)$ & 5 \\
\hline 2 & Investment in other assets & $3(75 \%)$ & $1(100 \%)$ & $1(100 \%)$ & 6 \\
\hline 3 & Proceeds from disposal of PPE & $4(100 \%)$ & - & - & 4 \\
\hline 4 & Dividends & $2(50 \%)$ & $1(100 \%)$ & - & 3 \\
\hline
\end{tabular}

Analysis of the adjustments used to compute Free Cash Flow (FCF), the second reported measure which has disclosure from all the industry groups in the sample, is reported in Table 5. Free cash flow is a measure of the liquidity of a firm after all operating and capital expenditure are accounted for. It is disclosed by six (14\%) of all discloser firms, this being made up of four of the 24 disclosing Real Estate firms (17\%), one of the 10 disclosing Cannabis firms (10\%), and one of the nine disclosing Blockchain/Cryptocurrency firms (11\%). Although the sample size of six is small it does provide insights into similarities and differences in the types adjustments made. This is potentially where the regulators could lend a hand and try to guide firms to minimize dispersion in adjustments.

Other than Free Cash Flow, the other most commonly reported non-GAAP financial measures noted in Table 3 are uniquely associated with sample firms in the Real Estate industry group. The finding that most of the disclosure of non-GAAP financial measures is observed in the sample of Real Estate firms may be due to the size and age of these firms, and the history of specialization in disclosing financial performance measures in the Real Estate industry (as is noted above and also discussed further below). Also, due to the emerging nature of Cannabis and Blockchain/Cryptocurrency industries, many of these firms will not yet be generating profits, operating cash flows, or other financial results on which commonly reported nonGAAP financial measures are based. 
The two other non-GAAP financial measures widely reported by Real Estate industry group are Funds from Operations (FFO) and Net operating Income (NOI). Table 6 presents a snapshot of the adjustments made to the funds from operations (FFO) one of the most common non-GAAP financial measure reported by sample firms in the Real Estate group, the most common adjustments are depreciation, amortization and fair value adjustments for Investment Properties. However, some firms adjust for not so common items like debt settlement cost or adjustments for joint venture accounting. Thus, we can note that even for the same non-GAAP financial disclosure, with in the same industry group, there exist differences in what adjustments firms make based on the nature of the expense/cost and potentially at their own discretion, limiting the consistency in financial disclosures. FFO which adjusts cash from operations to a more stringent measure of its operating cash position, is the, disclosed by $22(51 \%)$ of all firms, and $92 \%$ of the 24 disclosing Real Estate firms. TABLE 6: ANALYSIS OF TYPES OF ADJUSTMENTS USED TO COMPUTE FUNDS FROM
OPERATIONS (FFO)

\begin{tabular}{|l|l|l|}
\hline \multicolumn{2}{|l}{ Adjustment to Funds from operations } & $\begin{array}{l}\text { No. and (\%) of RE } \\
\text { Companies Adjusting } \\
\text { (Total 22) }\end{array}$ \\
\hline \multicolumn{2}{|l|}{} \\
\hline 1 & FV adjustments - Investment Properties & $17(77 \%)$ \\
\hline 2 & Amortization / Depreciation & $17(77 \%)$ \\
\hline 3 & Gain/Loss on Sale or Acquisition / Investment Properties & $16(72 \%)$ \\
\hline 4 & FV adjustment - Financial Instruments & $13(60 \%)$ \\
\hline 5 & Income Tax / Deferred Taxes & $12(54 \%)$ \\
\hline 6 & Acquisition Costs & $7(31 \%)$ \\
\hline 7 & Distribution on Limited Partnership Units & $4(18 \%)$ \\
\hline 8 & Interest Expense & $3(13 \%)$ \\
\hline 9 & FX Gain / Loss & $2(9 \%)$ \\
\hline 10 & Adjustments for Joint Venture Accounting & $2(9 \%)$ \\
\hline 11 & Non-recurring insurance settlements & $2(9 \%)$ \\
\hline 12 & Goodwill derecognition & $1(5 \%)$ \\
\hline 13 & Debt Settlement Cost & $1(5 \%)$ \\
\hline
\end{tabular}


Another common non-GAAP financial measure reported by firms in the Real Estate industry group is the Net operating income (NOI), which excludes any revenue or expense not directly associated with the firms operating or core income, is disclosed by 17 (39\%) of all disclosers, and $71 \%$ of the 24 disclosing Real Estate firms, where the most common adjustments are reported in the Table 7. Altogether there could be up to 12 different adjustments made to calculate NOI. The most common adjustment is direct property expense, which indicates some degree of consensus in industry specific adjustments. Other adjustments are not consistent across companies and points out unique adjustment firms make to calculate and report NOI, indicating a lack of consistency and comparability.

\section{TABLE 7: ANALYSIS OF TYPES OF ADJUSTMENTS USED TO COMPUTE NET OPERATING INCOME (NOI)}

\begin{tabular}{|l|l|l|}
\hline \multicolumn{2}{|c|}{$\begin{array}{c}\text { Adjustment to Net Operating Income } \\
\text { (NOI) }\end{array}$} & $\begin{array}{l}\text { No. and Percentage (\%) of Real } \\
\text { Estate Companies Adjusting } \\
\text { NOI (Total 17) }\end{array}$ \\
\hline 1 & Direct Property Expense & $12(70 \%)$ \\
\hline 2 & Tenant improvements & $5(30 \%)$ \\
\hline 3 & Share of Joint Venture & $4(23 \%)$ \\
\hline 4 & Realty Taxes or Income Taxes & $3(18 \%)$ \\
\hline 5 & Asset Management Fee & $2(11 \%)$ \\
\hline 6 & Straight Line Rents & $2(11 \%)$ \\
\hline 7 & FV adjustments of Investment Properties & $2(11 \%)$ \\
\hline 8 & Gain / Loss on Disposal & $2(11 \%)$ \\
\hline 9 & Residential Inventory & $1(6 \%)$ \\
\hline 10 & Sales and Cost of Sales & $1(6 \%)$ \\
\hline 11 & De-recognition of Goodwill & $1(6 \%)$ \\
\hline 12 & Trust Admin Expense & $1(6 \%)$ \\
\hline
\end{tabular}

One main observation, that addresses the first research question, is that the kind of non-GAAP financial measures that are reported and disclosed are similar among firms of the same industry group. For example, funds from operations are disclosed only by sample firms in the Real Estate group. This is due to the nature of operations as well as because of the guidance issued under the real estate industry's Whitepaper (REALpac, 2017). It states that firms should no longer report funds from operations in the 
financial performance section and that in compliance with Staff Notice 52-306, cash or funds from operations should be reported in the non-GAAP section. This result could be explained by the premise that each industry has different operations with longer business cycles and hence to inform the users, firms must disclose unique measures which reflect their true performance and operation. The most common measures in the Real Estate industry are FFO, NOI, and adjusted EBITDA.

For the Cannabis group, fewer firms choose to disclose the non-GAAP financial measures. This might be due to the still developing phase of the industry, and as years progress and the industry matures with the legalization of recreational marijuana in October 2018 (Cannabis Act, 2017) it is expected that a steep growth in the non-GAAP financial measures reported in the MD\&A shall be seen. Adjusted EBITDA, Cash Cost to Produce and Adjusted Product Contribution are the most common non-GAAP financial measures reported in the Cannabis industry.

\section{TABLE 8: ADJUSTMENTS TO CASH COST TO PRODUCE}

\begin{tabular}{|l|l|l|}
\hline \multicolumn{2}{|c|}{ Adjustment to Cash Cost to Produce } & $\begin{array}{l}\text { No. and Percentage (\%) of } \\
\text { Cannabis Companies Adjusting } \\
\text { (Total 3) }\end{array}$ \\
\hline 1 & FV of Biological Assets & $2(67 \%)$ \\
\hline 2 & Post production cost & $1(33 \%)$ \\
\hline
\end{tabular}

From Table 8, three Cannabis firms choose to disclose and report Cash cost to produce and while 2 of the firms choose to adjust for fair value of biological assets, one firm adjusts for post production cost.

\section{TABLE 9: ADJUSTMENTS TO ADJUSTED PRODUCT CONTRIBUTION}

\begin{tabular}{|l|l|l|}
\hline \multicolumn{2}{|c|}{$\begin{array}{l}\text { Adjustment to Adjusted Product } \\
\text { Contribution }\end{array}$} & $\begin{array}{l}\text { No. and Percentage (\%) of } \\
\text { Cannabis Companies Adjusting } \\
\text { (Total 3) }\end{array}$ \\
\hline 1 & FV of Biological Assets & $3(75 \%)$ \\
\hline 2 & Inventory write-downs & $1(25 \%)$ \\
\hline
\end{tabular}


The second most common measure across Cannabis firms is Adjusted Product Contribution, which is reported by three firms. Presented in table 9, where all three reporting firms adjust for fair value of biological assets and only one adjusts for inventory write downs. This bring out a very important finding, that although the adjustments might be of similar nature, the adjustment of even one different item makes it a new non-GAAP measure. Even if the two adjustments were the same, usage of different non-GAAP term and label makes it difficult for users to decipher such measures and understand them to their core.

Turning our attention to the last industry group, Blockchain/Cryptocurrency industry, it can be seen that 9 out of the 25 companies are disclosing non-GAAP financial measures such as adjusted EBITDA, Research and Development (R\&D) expense, and Return on Invested Capita (ROIC). ROIC is calculated and reported by 2 firms by dividing net income over average capital employed. $R \& D$ expense is a measure of the expenses incurred by the firm in new research, design and development and is common in technologybased firms and is a measure of future productivity and returns a firm can generate based on its current $R \& D$ initiative. It is interesting to note that during the data collection it was observed that this number increases significantly for the quarterly reporting in 2018 for Blockchain/Cryptocurrency firms but since this is outside of this study's inclusion criteria of 2017 MD\&A, it will not be discussed in this paper but worth looking into in the future.

A relevant point to highlight here is there exists a wide range of non-standardized terms used by firms. Firms use different measures and different labels while reporting the non-GAAP financial measure. This can be a limiting factor for an average investor to understand the label and what it is meant to inform them about the firm. For instance, although EBITDA and Adjusted EBITDA are two different non-GAAP financial measures, sometime firms use them interchangeably. To keep the richness of the data collected intact, the reported non-GAAP financial measure labels are the ones that the firms report and disclose without altering any of the terms reported in this section.

Out of the 74 firms I analyze, 31 firms do not report non-GAAP financial measures. I note, however, that 17 out of these 31 firms implicitly are reporting working capital as a performance measure, 
although without explicitly labeling it as a non-GAAP financial measure. A possible explanation for this is that working capital is an example of one of the measures that companies calculate using the GAAP numbers without any managers' adjustments, hence in essence it is a ratio calculated from GAAP numbers. This highlights the lack of understanding among companies with respect to some common measures like working capital and gross profit, as to whether they fall under GAAP or non-GAAP financial measure. For the purpose of this research, if the measure has been adjusted from a GAAP number, I treat it as "non- GAAP financial measure" using my judgement. Future research on such measures that fall in the grey area would be valuable. Also, further specific guidance from the regulators would be helpful in this area to avoid such inconsistencies.

\section{Discussion of results on non-GAAP financial measures reporting and adjustment analysis}

To summarize, the results of the content analysis points out abundant and dispersed use of nonGAAP financial measures. From a sample of 43 discloser firms, I have 74 different non-GAAP financial measures, so if a more representative, larger sample from the stock market is taken, the number of nonGAAP financial measures could go into hundreds if not thousands. Even the ones a firm gives a similar label to are not always comparable to another firm's non-GAAP financial measure, since the underlying adjustments to it might differ among firms. This is a discomforting finding as it indicates the non-GAAP financial measures across firms are not readily comparable. This also suggests that clear and enforceable guidance is essential to protect the user of financial statements from possible unreliable or misleading use of non-GAAP financial measures. The analysis and data collection point out towards the existence of a plethora of non-GAAP financial measures. In this sample, I find firms can make anywhere from two to 14 adjustment to calculate a non-GAAP financial measure. At times it appears if there is a parallel system of reporting running alongside the standard reporting system. This finding is of concern, particularly to the standard setters. Even if the firms are not making use of non-GAAP financial disclosures to distort or mislead, it still may suggest that the GAAP reporting systems are being found to be inadequate to provide useful information to users, and this is pushing firms towards resorting to these kinds of alternative 
measures. Some of these adjustments are common but not synonymous. This would be challenging not only for retail investors but also for analysts. Some measures are reported by a single firm only, which raises concerns about the relevance of that information and adjustment. Based on the above findings, reporting of non-GAAP financial measures in its current state is neither standardized nor comparable.

\section{DISCLOSURE SCORE ANALYSIS}

This sub-section addresses the third research question, examining the quality of non-GAAP financial disclosures of the sample of Canadian firms as measured by their compliance with the Canadian regulators' proposed disclosure guidelines. For this purpose, I follow up the content analysis findings for the sample of 43 disclosing firms and assess the quality of the non-GAAP financial measures disclosed by scoring each firm against the checklist with 24 parameters. An example of the checklist is provided in Appendix D. This checklist is adapted from the guidelines issued by the AcSB (AcSB, 2018a) and CSA (CSA, 2016; 2018c) to provide an objective approach for my scoring exercise. I score the non-GAAP financial measures in the disclosing firms' MD\&A across the parameters defined on my checklist. A score of 1 is given to a firm for compliance with each of the guideline parameters in the checklist and a 0 is given for non-compliance. The sum of the scores is labeled as the firm's disclosure score and a higher disclosure score is interpreted to mean higher quality disclosure. This disclosure score is my variable of interest to understand the behavior of firms in complying with the regulators' guidelines on non-GAAP financial measures and assess quality of non-GAAP financial disclosure.

To mitigate biased scoring, the firm names were coded. Additionally, interrater reliability is assessed by having two independent scorers perform the scoring for a sub-sample of 15 randomly selected MD\&As, representing $20 \%$ of my sample. The independent coders scored the non-GAAP financial disclosures based on the checklist and recorded their observations. Intraclass correlation statistic (ICC), one of the robust statistical measures of inter-rater agreement (Lu and Shara, 2007), was calculated in SPSS yielding a rank correlation of 0.88 and 0.85 , indicating a high level of reliability for my scoring approach. 
TABLE 10: DESCRIPTIVE STATISTICS FOR DISCLOSURE SCORES OF FIRMS' NON-GAAP FINANCIAL MEASURES

\begin{tabular}{l|l|l|l|l|l|l|}
\hline & N & Min & Max & Mean & Median & Std. Deviation \\
& & & & & & \\
\hline All 43 Disclosing firms & 43 & 5 & 20 & 11.9 & 12 & 3.25 \\
\hline Real Estate & 24 & 7 & 20 & 13.38 & 14 & 3.32 \\
\hline Cannabis & 10 & 8 & 12 & 10.10 & 10 & 1.45 \\
\hline Blockchain/Cryptocurrency & 9 & 5 & 13 & 10 & 11 & 2.59 \\
\hline
\end{tabular}

Table 10 reports the descriptive statistics for the disclosure score aross the sample of 43 firms as well as at each industry group level. The lowest possible score is zero and the highest possible score is 24 . The 43 disclosing firms have a mean disclosure score of 11.9 out of 24 which is $49.5 \%$ and well below the maximum possible score. The minimum score received by any firm from all the 43 firms is five and the maximum is 20 with a median and standard deviation of 12 and 3.25 respectively. Although the highest possible score that could have been earned by a firm is 24 , none of the firms are able reach to level of disclosure quality required by the regulators to earn the highest possible disclosure score which could easily be achieved if every guideline is adhered to by providing all relevant disclosures. Real Estate industry has 24 non-GAAP disclosers with a minimum and maximum earned scores of 7 and 20 respectively. The mean disclosure score for Real Estate is 13.38 with a median of 14 and standard deviation of 3.32. For the 10 Cannabis firms, mean disclosure score received by any firm in this group is below the All firm average at 10.1, median of 10 with a standard deviation of 1.45 and a minimum and maximum earned score of 8 and 12 respectively. The nine Blockchain/Cryptocurrency firms have achieved an mean disclosure score of 10 with a median of 11 and a standard deviation of 2.59 . The minimum score earned is 5 with a maximum score of 13 earned by any Blochchain/Cryptocurrency firm. The better disclosing firms are primarily coming from the Real Estate industry group and both the Cannabis and Blockchain/Cryptocurrency falling behind, which is understandable due to the extra scrutiny that Real Estate firms have faced in the CSA's recent review (CSA, 2018a). However Real Estate firms' variability in disclosure scores as reported by the 
standard deviation is higher than the other two industry groups which potentially is result of larger number of observation for Real Estate firms.

\section{TABLE 11: DISCLOSURE SCORES FOR 43 FIRMS DISCLOSING NON-GAAP FINANCIAL MEASURES ACROSS 24 PARAMETERS (SOURCE: AcSB, 2018a)}

\begin{tabular}{|c|c|c|c|c|c|}
\hline$\#$ & Description & $\begin{array}{l}\text { Total } \\
\text { Sample } \\
43 \text { Firms }\end{array}$ & $\begin{array}{l}\text { Real } \\
\text { Estate } \\
24 \text { Firms }\end{array}$ & $\begin{array}{l}\text { Cannabis } \\
10 \text { Firms }\end{array}$ & $\begin{array}{l}\text { Blockchai } \\
\text { n/Cryptoc } \\
\text { urrency } \\
9 \text { Firms }\end{array}$ \\
\hline 1 & $\begin{array}{l}\text { "Does the company identify and specify the } \\
\text { purpose of the reported performance measure? }\end{array}$ & $43(100 \%)$ & $24(100 \%)$ & $10(100 \%)$ & $9(100 \%)$ \\
\hline 2 & $\begin{array}{l}\text { Does the company explain why the chosen } \\
\text { performance measure is relevant to the } \\
\text { understanding of the strategy, objectives and } \\
\text { goals of the entity? }\end{array}$ & $5(12 \%)$ & $5(21 \%)$ & $0(0 \%)$ & $0(0 \%)$ \\
\hline 3 & $\begin{array}{l}\text { Does the company define the performance } \\
\text { measure? }\end{array}$ & $43(100 \%)$ & $24(100 \%)$ & $10(100 \%)$ & $9(100 \%)$ \\
\hline 4 & $\begin{array}{l}\text { Does the company explain the key } \\
\text { methodologies and assumptions including } \\
\text { components of the performance measure and } \\
\text { how it is calculated? }\end{array}$ & $31(72 \%)$ & $18(75 \%)$ & $5(50 \%)$ & $8(89 \%)$ \\
\hline 5 & $\begin{array}{l}\text { Does the company clearly explain how the } \\
\text { reported performance measure affects } \\
\text { compensation payouts? }\end{array}$ & $0(0 \%)$ & $0(0 \%)$ & $0(0 \%)$ & $0(0 \%)$ \\
\hline 6 & $\begin{array}{l}\text { Does the company provide targets (past and } \\
\text { future) for a performance measure? }\end{array}$ & $3(7 \%)$ & $3(13 \%)$ & $0(0 \%)$ & $0(0 \%)$ \\
\hline 7 & $\begin{array}{l}\text { Does the company provide how performance is } \\
\text { tracking against that target? }\end{array}$ & $2(5 \%)$ & $2(8 \%)$ & $0(0 \%)$ & $0(0 \%)$ \\
\hline 8 & $\begin{array}{l}\text { Does the company provide trend data and } \\
\text { explain management's actions given those } \\
\text { trends }\end{array}$ & $9(21 \%)$ & $8(33 \%)$ & $0(0 \%)$ & $1(11 \%)$ \\
\hline 9 & $\begin{array}{l}\text { Does the company refer to an industry or } \\
\text { sector-specific performance measure? }\end{array}$ & $24(56 \%)$ & $23(96 \%)$ & $0(0 \%)$ & $1(11 \%)$ \\
\hline 10 & $\begin{array}{l}\text { Does the company indicate whether a common } \\
\text { definition is used, and, if not, how the } \\
\text { definition used differs? }\end{array}$ & $33(77 \%)$ & $21(88 \%)$ & $9(90 \%)$ & $3(33 \%)$ \\
\hline 11 & $\begin{array}{l}\text { Does the company provide a performance } \\
\text { measure at the appropriate level of aggregation } \\
\text { and disaggregation to enable users to } \\
\text { understand the information? }\end{array}$ & $36(84 \%)$ & $19(79 \%)$ & $10(100 \%)$ & $7(78 \%)$ \\
\hline 12 & $\begin{array}{l}\text { Does the company specify source of the } \\
\text { performance measure? }\end{array}$ & $16(37 \%)$ & $13(54 \%)$ & $2(20 \%)$ & $1(11 \%)$ \\
\hline 13 & $\begin{array}{l}\text { Does the company specify assumptions of the } \\
\text { performance measure?" }\end{array}$ & $14(33 \%)$ & $11(46 \%)$ & $0(0 \%)$ & $3(33 \%)$ \\
\hline
\end{tabular}




\begin{tabular}{|c|c|c|c|c|c|}
\hline$\#$ & Description & $\begin{array}{l}\text { Total } \\
\text { Sample } \\
43 \text { Firms }\end{array}$ & $\begin{array}{l}\text { Real } \\
\text { Estate } \\
24 \text { Firms }\end{array}$ & $\begin{array}{l}\text { Cannabis } \\
10 \text { Firms }\end{array}$ & $\begin{array}{l}\text { Blockchai } \\
\text { n/Cryptoc } \\
\text { urrency } \\
9 \text { Firms }\end{array}$ \\
\hline 14 & $\begin{array}{l}\text { "Does the company specify limitations of the } \\
\text { performance measure? }\end{array}$ & $43(100 \%)$ & $24(100 \%)$ & $10(100 \%)$ & $9(100 \%)$ \\
\hline 15 & $\begin{array}{l}\text { Does the company use meaningful labels that } \\
\text { are clear? }\end{array}$ & $40(93 \%)$ & $22(92 \%)$ & $10(100 \%)$ & $8(89 \%)$ \\
\hline 16 & $\begin{array}{l}\text { The company does not describe as non- } \\
\text { recurring, infrequent or unusual if it has } \\
\text { occurred in recent years or is likely to occur in } \\
\text { the near future. }\end{array}$ & $42(98 \%)$ & $24(100 \%)$ & $10(100 \%)$ & $8(89 \%)$ \\
\hline 17 & $\begin{array}{l}\text { Does the company explain the rationale for the } \\
\text { adjustments to a GAAP financial measure? }\end{array}$ & $19(44 \%)$ & $12(50 \%)$ & $4(40 \%)$ & $3(33 \%)$ \\
\hline 18 & $\begin{array}{l}\text { Does the company explain why the non-GAAP } \\
\text { measure is more useful? }\end{array}$ & $9(21 \%)$ & $7(29 \%)$ & $1(10 \%)$ & $1(11 \%)$ \\
\hline 19 & $\begin{array}{l}\text { Is a GAAP financial measure is reported } \\
\text { equally prominent to a non-GAAP financial } \\
\text { measure? }\end{array}$ & $37(86 \%)$ & $19(79 \%)$ & $10(100 \%)$ & $8(89 \%)$ \\
\hline 20 & $\begin{array}{l}\text { Does the company include a reconciliation of a } \\
\text { non-GAAP financial measure (or component) } \\
\text { to GAAP in the annual report? }\end{array}$ & $35(81 \%)$ & $20(83 \%)$ & $9(90 \%)$ & $6(67 \%)$ \\
\hline 21 & $\begin{array}{l}\text { Does the company clearly explain why a new } \\
\text { performance measure is introduced and/or old } \\
\text { performance measure is modified.? }\end{array}$ & $10(23 \%)$ & $8(33 \%)$ & $0(0 \%)$ & $2(22 \%)$ \\
\hline 22 & $\begin{array}{l}\text { Explain why the new or a modified } \\
\text { performance measure is more relevant. Include } \\
\text { restated performance measures when needed. }\end{array}$ & $9(21 \%)$ & $7(29 \%)$ & $0(0 \%)$ & $2(22 \%)$ \\
\hline 23 & $\begin{array}{l}\text { Does the company state that it has developed } \\
\text { and reported a performance measure following } \\
\text { this, AcSB Framework or CSA guidelines? }\end{array}$ & $5(12 \%)$ & $5(21 \%)$ & $0(0 \%)$ & $0(0 \%)$ \\
\hline 24 & $\begin{array}{l}\text { Does the company state that a performance } \\
\text { measure is unaudited?" }\end{array}$ & $4(9 \%)$ & $2(8 \%)$ & $1(10 \%)$ & $1(11 \%)$ \\
\hline
\end{tabular}


The results of the disclosure scoring for the 43 sample firms which report non-GAAP financial measures are reported in Table 11, reporting the number of sample firms that meet each of the 24 checklist parameters. The breakdown across industry groups is also provided to show of the total companies in each industry group that meet the stated guideline.

Taking each parameter one by one, for parameter \#1 we see that $100 \%$ of the firms have properly identified and specified the purpose of the non-GAAP financial measures. Generally, the stated purpose is "to help users better evaluate the core and sustainable operations of the firm" or similar statements.

For parameter \#2, only five (12\%) of the 43 disclosing firms have linked the non-GAAP financial measures to the strategy of the firm and all of these five firms belong to the Real Estate industry group. That none of the other industry groups share this information is an interesting finding because if non-GAAP financial measures are more informative about the firm's operations, then they should be informative about the long-term success of the firm and hence should be tied with the strategy of the firm. This might be due to the early phase of the life of firms in the emerging Cannabis and Blockchain/Cryptocurrency industries. Future research designed specifically to investigate the reasons firms in these industries are not disclosing this information would be helpful to find a strong explanation for this finding, but this is beyond the scope of the current study.

There were no firms that did not define the non-GAAP financial measure used and clearly met the expectation laid out for parameter \#3. This is a positive finding since defining the measure is helpful for investors in understanding the non-GAAP financial information that the firm is trying to provide by reporting the measure.

With respect to parameter \#4, the methodology and assumptions behind the calculation of nonGAAP financial measures are clearly articulated by $72 \%$ of the firms, however, the adequacy of the level of detail given about the assumptions is debatable. This suggests that it would be helpful for the AcSB and CSA to provide their guidelines with a fine level of detail to reduce the grey areas left for firms while they prepare the non-GAAP disclosures, and so users can be more certain as to what to expect in the firms' nonGAAP financial disclosures. 
None of the firms have discussed the relationship of the non-GAAP financial measures with the firm's compensation plans as required to meet parameter \#5. This is of concern since many compensation contracts have some non-GAAP numbers tied to this, so this information must be shared with the users (Isidro and Marques, 2013). Future studies could examine it further to test for industry or other factors associated with compensation and non-GAAP financial disclosures.

Firms generally have been weak in providing historical and future data on non-GAAP financial measures. On a cumulative basis, for parameters \#6, 7 and 8 in Table 7, only 14 (33\%) of the 43 firms have reported targets, trends, or discussions on meeting or falling short of the targets for their non-GAAP financial measures. Generally, a trend analysis refers to multiple years on comparative tables being produced, whereas most of these 14 firms are only reporting year on year change. Out of the 14 firms, 13 belong to the Real Estate industry and one to the Blockchain/Cryptocurrency. None of the Cannabis firms are reporting historical or future data which is understandable due to the young age of this industry group. However, these findings also point toward the inherently uncertain nature of Cannabis and Blockchain/Cryptocurrency firms' operations, so that these firms' managers might be reluctant to commit to a future target.

For parameter \#9 only 24 firms, 23 of which belong to the Real Estate industry group, refer to sector specific measures, and this is mainly for the non-GAAP measures like FFO that are reported in conjunction with recommendations in the guidance from REALpac (2017). Since, for the reporting period that my study's data covers, the Cannabis and Blockchain/Cryptocurrency firms did not have CSA or other industry guidance, industry specific measures that could have been reported and disclosed would not have had the same kind of authoritative support as was the case for Real Estate firms. The CSA's recently conducted review of Cannabis firms (CSA, 2018d) does identify issues around lack of comparability of non-GAAP measures, however, and provides guidance on reporting them with cautionary wording and full disclosure. It would be interesting to examine the Cannabis industry group after some time to see the change in disclosure behavior post the review and guidance by CSA. For the same reason, only 33 firms, 21 of 
these are from the Real Estate, nine from Cannabis and only one in Blockchain/Cryptocurrency indicate whether a common definition is used and, if not, then how it differs.

For parameter \#10, 77\% of firms (33) indicate whether a common definition is used and if not, then how it differs. Although 33 firms do adequately address this parameter it is an extremely critical parameter for comparable non-GAAP financial measures and should have been disclosed by all firms. Twenty-one Real Estate, nine Cannabis and only three Blockchain/Cryptocurrency firms provide this explanation and might need some motivation or guidance to disclose it to the fullest.

Once a non-GAAP financial measure is identified, most of the firms (84\%) are able to provide an adequate level of aggregation and disaggregation for parameter \#11. Out of the 36 firms providing adequate level of aggregation and disaggregation, 19 belong to Real Estate, 10 to Cannabis and seven to Blockchain/Cryptocurrencies.

Firms do seem to struggle when providing source of the non-GAAP financial measure for parameter \# 12. Only $37 \%$ of all firms identify the source of non-GAAP financial measures, most of which belong to the Real Estate sector and identify the source of the non-GAAP performance measure coming from the REALpac (2017). This indicates that having industry-level guidance on non-GAAP financial measures would be beneficial in helping firms understand and explain how to report a certain measure. Only two Cannabis and one Blockchain/Cryptocurrency firms were able to identify such a source.

For parameter \# 13, only 33\% (14) of firms explain the assumptions of the performance measure, where 11 of these firms belong to the Real Estate sector and 3 to Blockchain/Cryptocurrency. None of the Cannabis firms provide the assumptions and it might be due to still developing phase of the industry.

When it comes to specifying the limitations in accordance with parameter \#14 of the non-GAAP financial measures, $(100 \%)$ of firms make a general statement that warns users to use the non-GAAP financial measures with caution as they are not standardized and do not carry the same meaning as the GAAP measures or other non-GAAP financial measures reported in the industry. The current guidelines have some level of ambiguity in the expected information detail they want firms to disclosure with respect 
to non-GAAP financial measures limitations. If the proposed disclosure guidance is to have the desired efficacy, these concerns will need to be addressed.

For parameter \#15, firms do use meaningful and clear labels. However, we do know from our descriptive adjustment analysis in the previous section that the list of such labels is long. While 93\% of firms meet this parameter with good adherence across all three industry groups, thought that label might be clear and understandable at firm level, it has severe comparability issues at industry level.

A recurring area of concern to the regulators and analysts equally has been the exclusion of recurring and non-transient items from the non-GAAP financial measures. For disclosure parameter \#16, I find that $42(98 \%)$ of the sample firms are consistent in their exclusions and inclusions of transitory items from 2016 to 2017. The results across the industry groups are encouraging as they all seem to be in sync with the idea of not cherry picking to report better performance. The two firms that not consistent in their adjustments are from the Blockchain/Cryptocurrency industry, indicating more specific guidance might be required for this relatively newer industry group. It is less encouraging, however, that not all the firms who adjust provide adequate rationale for the adjustment. For parameter \#17, I find that only 19 (44\%) firms of the 43 firms disclose the rationale behind their adjustments. This could potentially be due to lack of understanding on part of firms reporting the adjustments as to the level detail required by the regulators. This seems to be a likely explanation because if a firm is disclosing its adjustments, then sharing the rationale for these adjustments would not be so onerous to neglect. Of these 19 firms, 12 firms belong to Real Estate, four to Cannabis and the remaining belong to the Blockchain/Cryptocurrency industry group. Additional guidance may be required to inform the firms of users' expectations for clear rationales when discussing their adjustments.

For parameter \#18, only nine $(21 \%)$ of the firms clearly state why the non-GAAP financial measures are more useful than GAAP measures. When firms explain the rationale for disclosing non-GAAP financial measure, they only superficially explain using statements such as, "it is a better indicator of their performance and operations". The expectation is, however, to be more specific in defending their choice to disclose the non-GAAP financial measure and why they perceive it to be a better measure of the comparable 
GAAP number or even point to a limitation they see in the GAAP measure. All industry groups fall short on this parameter.

Prominence, parameter \#19, is being adhered to by 37 (86\%) of the firm, made up of 19 fromReal Estate, 10 from Cannabis and eight from Blockchain/Cryptocurrency. This is an encouraging aspect but at the same time raises concerns that if firms do report non-GAAP financial measures prominently, then why do they not provide information required by items on the guideline so that this reporting is more informative? Is it a herding behavior, indicating that just firms are trying to do what they see other firms doing without strong motivations of their own to provide meaningful information to users, or do firms actually do look at the guidelines? However, since the data for this study is limited to the MD\&A, it would be interesting to examine all parameters in other communications of the firm, as the front end of the annual report, twitter, earnings call, etc. to examine prominence aspects more comprehensively.

For parameter \#20, 81\% of disclosers, 35 firms, are providing reconciliation of non-GAAP financial measures comprising of 20 Real Estate firm and all nine Cannabis firms providing reconciliation. Blockchain/Cryptocurrency firms are weakest in providing reconciliation with six firms out of nine presenting the reconciliation of non-GAAP financial measures.

For parameters \#21 and 22 regarding the firms' compliance with making proper disclosure when a non-GAAP financial measure is introduced for the first time or has been modified, it is discomforting to find a high level of non-compliance. Only $10(23 \%)$ firms identify explicitly and clearly state any such change, and only (8) $21 \%$ discuss why the new measure is more relevant. Out of the 10 firms, eight belong to Real Estate and two are from the Blockchain/Cryptocurrency industry group. Interestingly, at times, firms do report a comparative number for last year without any identification, and upon examining the prior year's MD\&A, it was discovered that the measure did not exist last year. This would be of particular concern to the users, as it lowers the reliability of the MD\&A when comparative data cannot be traced back to what the firm provided in its prior year reports.

Looking at parameter \#23, even though Staff Notice 52-306 has been available to firms as guidance to use while preparing the non-GAAP financial measures since 2003, not many firms recognize the 
existence of it in their MD\&A. Some of them do mention NI 52-112, which is has broad disclosure guidelines but not the Staff Notice 52-306 which is specifically geared towards non-GAAP financial measures. Only five firms, all in the Real Estate group, recognize that the disclosures in MD\&A are in accordance with the Staff Notice 52-306.

To address parameter \#24, only four (9\%) out of the 43 firms explicitly state that the MD\&A is not audited. For the $91 \%$ of firms that remain silent on this point, while it could just be an oversight, on the contrary it also could indicate a firm is trying to mislead users by leveraging the assurance from the audited financial statements to imply this applies to the unaudited MD\&A. Further field or experimental research could examine whether users are aware that the MD\&A is not audited.

There are additional insightful findings from the disclosure score of the MD\&A. Not all firms adequately recognize the existence of non-GAAP financial measures in the preface of the MD\&A and some would introduce the definitions after using the measure multiple times to report their performance. Extending from the previous point, there is a lack of consensus with respect to labeling non-standardized measures as either "non-GAAP", "non-IFRS" or some other term. The only industry that is consistent in their nomenclature is the Real Estate industry. This could be attributed to the recent scrutiny Real Estate companies have had from the CSA in 2017. Additional this could also be the result of an industry-wide practice of disclosing non-GAAP financial measure in accordance with an industry white paper (REALpac, 2017).

\section{Summary of MD\&A Disclosure Scoring}

In summary, the disclosure analysis and scoring results show that firms are falling short of benchmarks that the AcSB guidelines and NI 52-112 propose on parameters such as understandability, clarity, comparability, standardization, and persistence. The criteria prescribed in Staff Notice 52-306 has been addressed by some but not by all firms. Even those who make disclosures of non-GAAP financial measures are superficially touching upon it and not providing the level of detail needed for transparency, comparability, and understandability. None of the firms link the non-GAAP financial measures to the company's strategy and compensation. The majority of firms fail to give detailed underlying assumptions 
when they calculate the non-GAAP financial measures. Firms are unable to identify and specify the relevance of the particular non-GAAP financial measure, the only blanket statement they make is that, "We believe this measure is useful in understanding the operations of the firm". Generally, the only areas where firms comply with the guidance are in providing the definitions and labeling of the non-GAAP financial measures, prominence and reconciliation. Modifications appear to be an important area that is being overlooked. Firms fail to recognize a change or introduction of a new non-GAAP financial measure. Although some of them provide a recalculated measure of last year, failure to recognize that it is a new or modified measure is rather misleading and misrepresenting. From the average disclosure score of 11.9 (49.5\% of the maximum possible of 24 ) it is evident that there is a deficiency on part of firms when disclosing non-GAAP financial measures in accordance with the guidance issued by the regulators, with better disclosing firms coming from the Real Estate industry group with a score of 13.3 (56\%) which is due to the recently guidance issued for Real Estate firms have by the CSA (CSA, 2018a), which supports my position that regulation of non-GAAP financial measures would minimize issues around understandability, comparability, reliabiltiy and relevance and, in turn, benefit all market participants. (Akerlof, 1970)

To conclude the descriptive study and disclosure scoring; the analysis and findings presented above addresses the three research questions of this study, as follows:

RQ1: The findings show that the various and common non-GAAP financial measures Canadian firms choose to disclose are large in number. These non-GAAP financial measures are varied and dispersed, and while firms that belong to one industry group generally choose to disclose similar non-GAAP financial measures, the reported measures are not perfectly standardized.

RQ2: My content analysis of adjustments show that there is lack of consistency among firms, even within the same industry group, when they make adjustments to GAAP measures and convert them to non-GAAP financial measures. Hence in its current form, non-GAAP financial measures are not comparable.

RQ3: My disclosure scoring assesses the quality of non-GAAP financial disclosures as measured by their compliance with the regulatory guidelines. The results of the disclosure scoring points towards weak adherence with the existing guidelines and hence, on an average, low quality of non-GAAP financial 
disclosures. These findings support the need for enhanced guidance that will provide effective regulation related to increasing the quality of disclosure of non-GAAP financial measures.

\section{Additional Preliminary Analysis}

In the last part of this study, which flows from the natural progression of the disclosure scoring and data collected, I performed a preliminary analysis to test some of the factors associated with non-GAAP disclosures, primarily the ones I had collected or came across during the content analysis. Another compelling objective for performing these tests is to practice applying basic statistical techniques for a master's research project. Results from the models must be interpreted with caution due to limitation of the econometric models as a result of limited sample size, which is not representative of the population, and due to control variables that have been omitted (including but not limited to) leverage, age of firm, TobinQ, assets, size and growth etc. Future studies are planned to be undertaken with robust theoretical framework and test models, with more explanatory power, for the impact of these variables. In this section I include some of the literature that forms the basis for this preliminary analysis, followed by the methodology and results from this analysis.

Healy and Palepu (2001) posit that non-GAAP financial measures are from the manager's eyes who have firsthand information about the sustained operations and future profitability of the firm. We can extend their and suggest that firms choose to disclose non-GAAP financial measure when they have some useful and relevant information to communicate to the users. Typically, greater analyst following is considered to be indicative of the choice to disclose more information and of higher quality disclosure (Christensen et al., 2017a). Through my preliminary analysis I seek to test and confirm for my sample, whether it is the demand from the analysts that drive this disclosure or is it the profits and losses that motivate firms to strategically disclose non-GAAP measures (Leung and Veenam, 2018).

Bentley et al. (2018) posit that analysts' attention to non-GAAP financial measures performs the same function as constant monitoring would, and the quality of disclosure, gauged through quality of adjustments, 
is better in analyst presence. I extend this to test if quality of non-GAAP disclosure, measured through my disclosure score, is associated with analyst following. More analyst following is considered to be indicative of higher quality as firms attempt to provide good quality disclosure as they are not opportunistic and want to furnish additional useful information to assist stakeholders in decision making.

Another study which I will bring in for my analysis is based on the findings of Leung and Veenam (2018) who conclude that loss-making firms compensate for low informativeness of GAAP losses by making exclusions. If we extend this to my study, then the choice to disclose as well as quality of disclosure (disclosure score) should be influenced by whether the firms make a profit or a loss.

From my descriptive analysis I know that not all firms have lower quality non-GAAP financial disclosures. Some firms do have a higher disclosure score than others and based on content and disclosure score analysis it evident that Real Estate firms have a higher mean disclosure score and hence there potentially might be an industry association with the quality of non-GAAP financial disclosure.

Based on these prior studies and on my content analyses, the preliminary analysis explores whether the motivation for the sample of Canadian firms is informative or opportunistic to see what drives the quality of the reported non-GAAP financial measures. Quality of non-GAAP financial measures in presence of analyst following, profit or loss and industry affects on non-GAAP financial disclosures are tested using regression models.

To address these questions, I conduct a preliminary empirical analysis to test the association between;

i. Disclosure of non-GAAP financial measure and analyst following (information demand)

ii. Disclosure quality and its association with analyst following, financial performance and industry group (opportunism vs informativeness)

Most of the data for the preliminary analysis is already available from the MD\&A analysis exercise. Table 12 defines each variable with its source. Additional information on analyst following was collected from the firms' websites, information on firms' profits and losses was extracted from the annual reports, and market capitalization was taken from TSX and TSXV data. 
TABLE 12: VARIABLES FOR PRELIMINARY ANALYSIS

\begin{tabular}{|c|c|c|}
\hline \multicolumn{2}{|c|}{ Variable Description } & \multirow{2}{*}{$\begin{array}{l}\text { Source } \\
\text { From MD\&A content analysis }\end{array}$} \\
\hline DISCit & $\begin{array}{l}\text { A binary dependant variable that is } 1 \text { for firms that } \\
\text { choose to disclose non-GAAP financial measures and } \\
0 \text { for firms that do not. }\end{array}$ & \\
\hline$A N F O L_{i t}$ & Number of Analyst following the firm & From the firm's website \\
\hline$P L_{i t}$ & $\begin{array}{l}\text { A binary variable, where } 1 \text { is assigned to firms with } \\
\text { positive GAAP income and } 0 \text { is assigned to firms } \\
\text { with negative GAAP net income. }\end{array}$ & $\begin{array}{l}\text { From the Annual reports of the firm for } \\
2017\end{array}$ \\
\hline$R E_{i t}$ & $\begin{array}{l}\text { Dummy control variables for Real Estate firms, } \\
\text { where } 1 \text { is given if it falls in the industry; } 0 \\
\text { otherwise. }\end{array}$ & From MD\&A content analysis \\
\hline MKTCapi & A control variable for the size of the firm & From TSX/TSXV for 2017 \\
\hline Score $_{i t}$ & $\begin{array}{l}\text { Disclosure score assigned as a result of the disclosure } \\
\text { analysis and scoring }\end{array}$ & From disclosure analysis and scoring \\
\hline
\end{tabular}

TABLE 13: SAMPLE FOR PRELIMINARY ANALYSIS

\begin{tabular}{|lllll|}
\hline & Real Estate & Cannabis & Crypto & Total \\
\hline Sample Collected & 25 & 25 & 25 & 75 \\
\hline Firm lost due to missing MD\&A & $(1)$ & 0 & 0 & $(1)$ \\
\hline Firms lost due to missing market capitalization values & 0 & 0 & $(2)$ & $(2)$ \\
\hline Firms lost due to Merger and Acquisition & $(1)$ & $(1)$ & 0 & $(2)$ \\
\hline Final Sample for additional empirical analysis & 23 & 24 & 23 & 70 \\
\hline Non-GAAP disclosers & 23 & 9 & 8 & 40 \\
\hline Non-GAAP non- disclosers & 0 & 15 & 15 & 30 \\
\hline
\end{tabular}

For additional preliminary analysis, after allowing for missing market data and mergers \& acquisitions, the sample size was reduced to 70 companies, as reported in Table 13. The full sample of 70 companies comprised of 23 Real Estate firms, 24 Cannabis firms and 23 Blockchain/Cryptocurrency firms. 
For the preliminary analysis, I designed two models: Model 1 performs an empirical test for the likelihood of a firm to disclose non-GAAP financial measures in presence of analyst following, profits/losses and industry group.

$D_{I S C} C_{i t}=b_{0}+b_{1} A N F O L_{i t}+b_{2} P L_{i t}+b_{3} S e c R E_{i t}+b_{4} M K T C a p_{i t}+\varepsilon_{i}$ (Model 1)

Model 1 is a logit model and is based on Mahoney et al. (2013), where, DISC is a binary dependant variable that is 1 for firms that choose to disclose non-GAAP financial measures and 0 for firms that do not. ANFOL is analyst following, which is taken from the company's website and PL is a binary variable, where 1 is assigned to firms with positive GAAP income and 0 is assigned to firms with negative GAAP net income. MKTCap is included as a control variable for the size of the firm similar to Bhattacharaya et al. (2007). SecRE are dummy control variables for Real Estate firms, where 1 is given if it falls in the industry; 0 otherwise. This is a variable of interest to examine if industry has influence on a firm in its choice to disclose non-GAAP financial measures based on my content analysis. $b_{o}$ is intercept, $b_{s}$ are coefficients, " $\mathcal{}$ " is error term. " $t$ " is time subscript. Due to the nature of my data, model 1 is estimated by employing the Binary Logit estimation technique which is most suitable for my analysis as my dependant variable is binary in nature with more than one independent variable

Model 2 is based on Bewley and Magness (2008). It tests for association of disclosure quality of non-GAAP financial measures with analyst following, profit/loss and industry group. This is extending Leung and Veenman (2018), to see if firms are strategically disclosing or cherry picking to report nonGAAP financial measures.

Model 2

Score $_{i t}=b_{0}+b_{1}$ ANFOL $_{i t}+b_{2} P L_{i t}+b_{3} \operatorname{SecRE}_{i t}+b_{4} M K T C a p_{i t}+\varepsilon_{i .}$ (Model 2)

In Model 2, SCORE is a dependent variable, which is the disclosure score assigned as a result of the disclosure analysis and scoring. My variables of interest are analyst following (ANFOL), profit or loss (PL) and Real Estate firms (SecRE). MKTCap is the control variable. SecRE is a dummy control variable 
for Real Estate firms, where 1 is given if it falls in the industry; 0 otherwise and based on my disclosure score analysis I expect that there would be an association between industry and disclosure score. " $\mathrm{t}$ " is time subscript, $b_{o}$ is intercept and $b_{s}$ are coefficients, and " $E$ " is error term. Based on the nature of my data, the model is estimated using ordinary least square (OLS) estimation method which is suited to incorporate dummy variables into the model with multiple predictor variables for the dependant variable. Although multicollinearity and non-linear could potentially be a limitation in this model but since there are only five independent variables, the impact may be moderate and worth exploring in future studies. 


\section{Descriptive Statistics}

This paragraph presents and discusses descriptive statistics of the data for non-GAAP financial measures, namely, 2017 market capitalization, analyst following, and profit and loss. Table 14 also reports the distribution of sample. The descriptive statistics are presented in two panels whereas Panel A represents descriptive statistics of all the firms who disclose or do not disclose non-GAAP financial measure, while Panel B exclusively presents descriptive statistics of companies that report non-GAAP financial measure.

\section{TABLE 14: DESCRIPTIVE STATISTICS}

Panel A: Descriptive Statistics for Sample of non-GAAP financial measure disclosers and nondisclosers

\begin{tabular}{|l|l|l|l|l|l|l|}
\hline \multicolumn{2}{|c}{ N Minimum } & Maximum & Mean & Median & Std. Deviation \\
\hline $\begin{array}{l}\text { Market Capitalization } \\
\text { 2017 (C\$ M) }\end{array}$ & 70 & 0.214 & 7892 & 1322.85 & 185.88 & 1914 \\
\hline Analyst Following & 70 & 0 & 19 & 4.82 & 2.5 & 5 \\
\hline $\begin{array}{l}\text { Non-GAAP Disclosers } \\
\text { Score }\end{array}$ & 40 & 0 & 5 & 20 & 11.4 & 11.5 \\
\hline Non-Disclosers & 30 & N/A & N/A & N/A & N/A & N/A \\
\hline Real Estate firms & 23 & N/A & N/A & N/A & N/A & N/A \\
\hline Other firms & 47 & N/A & N/A & N/A & N/A & N/A \\
\hline Profit firms & 32 & N/A & N/A & N/A & N/A & N/A \\
\hline Loss firms & 38 & N/A & N/A & N/A & N/A & N/A \\
\hline
\end{tabular}

Panel B: Descriptive Statistics for non-GAAP financial measure disclosure firms

\begin{tabular}{|l|l|l|l|l|l|l|}
\hline \multicolumn{2}{|c}{ Ninimum } & Maximum & Mean & Median & Std. Deviation \\
\hline $\begin{array}{l}\text { Market Capitalization } \\
\text { 2017 (C\$ M) }\end{array}$ & 40 & 3.13 & 8343 & 2377 & 2098 & 2369 \\
\hline Analyst Following & 40 & 0 & 19 & 6.4 & 5 & 4.477 \\
\hline Disclosure Score & 40 & 5 & 20 & 11.4 & 11.5 & 3.303 \\
\hline Real Estate firms & 23 & N/A & N/A & N/A & N/A & N/A \\
\hline Other firms & 17 & N/A & N/A & N/A & N/A & N/A \\
\hline Profit firms & 30 & N/A & N/A & N/A & N/A & N/A \\
\hline Loss firms & 10 & N/A & N/A & N/A & N/A & N/A \\
\hline
\end{tabular}

Table 14 panel A presents the descriptive statistics for the 70 firms, where 40 firms disclose nonGAAP financial measures and the remain 30 do no report the non-GAAP financial measures. There are 32 
firms in the sample that post profit for 2017 and 38 firms that post losses, primarily belonging to Cannabis and Blockchain/ Cryptocurrency firms. The average analyst following, which is an independent variable, for all sample firms is 4.82 with a median and a standard deviation of 2.5 and 5 respectively. The Minimum number of analysts following is 0 with a maximum of 19. Minimum market Capitalization is 0.214 million with a maximum 7892 million and an average of 1332.85 million. The standard deviation is 1914 million and median 185 million. The minimum score of 0 is for firms that choose not to report any non-GAAP financial measure with a maximum score of 20.

Similarly, minimum values, maximum values, mean values, median and standard deviation of relevant variables, from subsample of 40 firms that report non-GAAP financial measure are presented in Panel B of Table 14. There are 30 firms in the sample that post profit for 2017 and 10 firms that post losses. Disclosure scores, which is a variable of interest has a minimum value of 5 and a maximum 20. The mean for disclosure score is 11.4 with a median of 11.5 and standard deviation of 3.303 . It can be seen that the mean for analyst following increased from 4.8 for the entire sample to 6.4 for the subsample of 40 firms that report non-GAAP financial measure, indicating that firms that disclose non-GAAP financial measures tend to have greater analyst following.

\section{Univariate relations}

Table 15 reports the correlation between the continuous variables, disclosure score and analyst following, for the sample of 40 firms that report and disclose non-GAAP financial measures. The first measure of correlation that I use is the Pearson Correlation which shows linear relationship between two continuous variables. Correlation between analyst following and disclosure score is 0.350 based on Pearson correlation an which is significant at 0.05 level and indicates that disclosure scores are correlated with analyst following. The other measure I report is the Spearman's rho which is a variant and a nonparametric version of Pearson correlation. The Spearman's correlation looks at the ranked or ordinal data variables for strength and direction of correlation (Stock and Mark, 2011). It provides similar results, indicating the strength of relationship between analyst following and disclosure score is significant at 0.436 at 0.01 level of significance. Since the correlation from Spearman's correlation is higher than the correlation from 
Pearson's correlation, it indicates that the relationship between analyst following and disclosure score is monotonic and increasing. This confirms Christensen et al. (2017a) that disclosure quality of non-GAAP financial measures is positively associated with analyst following, which acts as a natural regulation and monitoring for good quality non-GAAP financial disclosures.

\section{TABLE 15: CORRELATIONS}

\begin{tabular}{|l|l|}
\hline Pearson's Correlation & Analyst Following and Disclosure Score \\
\hline Spearman's Correlation & $0.350^{*}$ \\
\hline $\begin{array}{l}* * \text { Correlation is significant at the } 0.01 \text { level (2-tailed). } \\
\text { *. Correlation is significant at the } 0.05 \text { level (2-tailed). }\end{array}$ \\
\hline
\end{tabular}

\section{Results of empirical tests}

Results of the empirical tests are presented in Table 16. Panel A shows the results from Model 1, and Panel B shows the results from Model 2.

Logit Model was used to estimate the predictors for disclosing vs not disclosing non-GAAP financial measures in model 1 with the full sample of 70 firms. The preliminary results presented in Table 16, panel A, show that firms' disclosure vs non- disclosure decision is significantly associated with analyst following with a coefficient of $0.64(\mathrm{z}=7.612)$ with a significance of $0.006(\mathrm{p}<0.05)$ and that the more the analyst following, the more likely will firms disclose non-GAAP financial measure. Generally, this may suggest that firms with more analyst following are more likely to provide voluntary non-GAAP financial measure disclosures. The remaining estimates from this model are not found to be significant. Overall, due to the econometric limitations of this preliminary analysis, the findings require further testing under a rigorous research design to support any valid inferences.

The second preliminary test estimates the association between the quality of non-GAAP disclosures, measured by the disclosure score as a dependent variable and profits or losses of firms, analyst following and industry group as independent variables. This model is estimated using the OLS regression 
method and results are reported in panel B of table 16. The sample is for the 40 firms that report non-GAAP financial measures. Analyst following is estimated to be marginally significant at 0.1 level with a coefficient of $0.256(t=1.815)$ and " $p$ " value of 0.078. SecRE is also significant with coefficient at $0.491(t=2.66)$ and a "p" value of 0.012 which is significant at 0.05 level. For the model fitness, F statistic is 3.455 and $\mathrm{R}$ squared is $25.3 \%$.

The remaining estimates from this model are not found to be significant. Overall, due to the econometric limitations of this preliminary analysis, the findings require further testing under a rigorous research design to support any valid inferences. Further, the industry effects are different under both models, further examination is warranted in future studies with appropriate industry controls.

Subject to the research limitations, the results of estimating the two preliminary analysis models do indicate that disclosure of non-GAAP financial measures in the study sample is associated with analyst following, which would suggest it is the information demand that motivates firms to disclose these alternative measures. However as already stated in the beginning, the findings of the preliminary analysis are not generalizable or robust and need to be tested further under a rigorous research design. 
TABLE 16: RELATION BETWEEN NON-GAAP FINANCIAL MEASURES, ANALYST FOLLOWING, PROFITS/LOSS AND DISCLOSURE SCORE

Panel A-Logit Regression

Dependent Variable: NON_GAAP_MEASURES_USED_

\begin{tabular}{|c|c|c|c|c|}
\hline Variable & Coefficient & Std. Error & z-Statistic & Prob. \\
\hline ANALYST_FOLLOWING & 0.640 & .232 & 7.612 & 0.006 \\
\hline PROFIT_OR_LOSS & -1.147 & 1.611 & 0.507 & 0.317 \\
\hline MARKET_CAP_2017 & $3.45 \mathrm{E}-11$ & $1.54 \mathrm{E}-11$ & 0.597 & .0440 \\
\hline INDUSTRY RE & 20.584 & 6824 & 0.0001 & 0.997 \\
\hline $\mathrm{C}$ & -3.011 & 0.752 & 16.008 & 0.049 \\
\hline Nagelkerke R-squared & 0.849 & & $\begin{array}{l}\text { cance } \\
\text { LR statistic) }\end{array}$ & $\begin{array}{l}0.889 \\
0.00000\end{array}$ \\
\hline
\end{tabular}

Panel B-OLS Regression

Dependent Variable: Disclosure Score

Variable Coefficie

\begin{tabular}{lllll}
\hline ANALYST_FOLLOWING & 0.256 & 0.104 & 1.815 & 0.078 \\
PROFIT_OR_LOSS & -0.064 & 1.293 & -0.373 & 0.711 \\
MARKET_CAP_2017 & 1.26 & 0010 & 0.803 & 0.428 \\
INDUSTRY RE & 0.491 & 1.218 & 2.66 & 0.012 \\
C & 8.270 & 1.018 & 8.125 & 0.0000 \\
\hline
\end{tabular}

\begin{tabular}{llll}
\hline \hline R-squared & 0.394 & Adjusted R-squared & 0.325 \\
F-statistic & 5.697 & Prob(F-statistic) & 0.001
\end{tabular}




\section{CONCLUSION}

This study provides further evidence in support of existing studies on the proliferation of various non-GAAP financial measures. Based on the findings, despite the similarities in reporting and adjusting non-GAAP financial measures within an industry group, the current state of reporting on non-GAAP financial measures is neither standardized nor comparable. This poses a threat to efficient markets. Furthermore, this paper indicates a lack of consistency among firms when making adjustments to report the non-GAAP financial measure and which would ultimately make the financial information less comparable.

Evaluation of the non-GAAP financial disclosures in MD\&A against the existing guidelines issued by the CSA in form of Staff Notice 52-306 raises concerns about the quality of non-GAAP financial disclosures, in that firms appear to be falling short in meeting the expectations of disclosure as defined by CSA. Findings from the disclosure scoring and MD\&A analysis suggest that regulation of nonGAAP financial measures is desirable to curtail misleading and obscure disclosures, consistent with Hoogervorst, (2015) and Shumsky (2016). Thus, the AcSB's guidance on defining a consistent metric, reporting, presentation, and regulation of non-GAAP disclosure is relevant and timely. From the findings of this study, it is evident that firms fall short on providing disclosures in accordance with the existing and proposed guidelines. Current CSA Staff Notices and guidelines have generally been ignored and not given due importance by preparers of financial information. Therefore, it warrants strengthening the enforceability of NI 52-112 for it to have the desired efficacy. Regulators should also attempt to clearly state their expectation for non-GAAP disclosures. It can be seen that the interpretation of the current guidelines can be different, which is leading to a widening gap in the expectations of firms and regulators. Perhaps the AcSB and the CSA could aim to define the guidelines to finer details to minimize grey areas for firms while they prepare the non-GAAP financial disclosures. This conclusion is supported by a recent letter issued from AcSB to CSA, in which AcSB indicates that it would be amending its draft guidelines to reflect improved explanation and to be consistent terminology used in the CSA framework (AcSB, 2018b). 
The main contribution of this paper is the unique approach taken to undertake a content analysis to examine the existing firm practices of reporting non-GAAP financial measures of Canadian listed companies across three industry groups, which no other study has done. This study analyzes hand collected data and provides evidence and findings from Canadian listed companies which are relevant to the CSA and AcSB. After NI 52-112 is enforced, it is expected that the quality of non-GAAP disclosures will increase (Christensen et al., 2017b). Audit and assurance could help improve the quality of non-GAAP disclosures (Chen et al., 2017) and add reliability to the non-GAAP numbers. This study iterates the need for assurance for the non-GAAP financial measures in the MD\&A called in for by Cole and Jones (2005). This would improve the consistency and transparency of non-GAAP financial measures. As a further, practical contribution of this study, I have prepared a comment letter to the CSA based on the study's key findings.

These implications are not only relevant for capital market investors but also for regulators, standard setters, analysts, and auditors. This study is based on Canadian listed companies and further examination is warranted to examine firms in other industries in Canada for similarities or differences in their choice of non-GAAP financial disclosures. It might also be worthwhile to explore industryspecific guidelines similar to the ones given by REALpac (2017) or the Sustainability Accounting Standards Board (SASB) where each industry has a set of guidelines to help them disclose operations and performances unique to their industry in a more synchronized and systemic manner. 


\section{LIMITATIONS}

For the purpose of this research, most of the data was hand collected from the MD\&A, and disclosure scores to gauge quality of non-GAAP disclosures were assigned manually. Any error in collecting and coding data is attributed to the author. One of the biggest limitations of this study is assigning the disclosure score so some element of subjectivity is unavoidable. However, to address this concern, the draft guidelines issued by AcSB and CSA have been used as a basis for the scoring checklist to minimize biased evaluation of non-GAAP financial disclosures. Additionally, for greater validity, interrater reliability was assessed by two independent scorers yielding a rank correlation of 0.88 and

0.85. The trade-off of this exploration and hand collection of data is a richer and less obscure data not available in existing studies. Nonetheless, some degree of judgment is inevitable and must be interpreted with caution.

The findings of this study are based on a limited sample of Canadian companies selected from three industries and not generalizable to other companies and industries. This is a limitation; however, one of the inferences that can be drawn from this study is that each industry has its unique performance measures and operations, and hence different non-GAAP financial measures are reported, which could be examined in detail in future studies. Since this study is primarily exploratory and its sample selection was designed to identify firms most likely to be reporting a range of non-GAAP measures. Additional empirical tests were performed on a very preliminary basis to investigate if non-GAAP financial measure disclosure is associated with analyst following in the sample firms, but due to the nature of the sample and limited control variables used in the models for analysis, no conclusive statements can be made about the empirical findings. Future research should aim to collect a more broadly-based sample of firms and incorporate relevant control variables, such as age of firm, sales growth and leverage, to provide a more robust empirical analysis. Furthermore, since the data for this study is limited to the MD\&A, it would be interesting to examine all non-GAAP financial measure parameters in other communications of the firm, such as the front end of the annual report, Twitter, analysts calls, earnings announcements, and social media. 


\section{FUTURE RESEARCH}

Non-GAAP financial measures is a topic of current and foreseeable changes and reforms. This study has raised questions which could be further examined and add value to the existing knowledge on the topic. Therefore, there is much that the research community can study and contribute to this area.

Currently, non-GAAP financial measures are not required to be audited which gives room to firms for reporting non-GAAP numbers in their communications to project a better performance than represented by the GAAP reports. Although the expectation is for the non-GAAP financial measure to be honest and informative, markets do rely on the audit for monitoring and control. Further study is warranted in the area of assurance of non-GAAP financial measures. If regulators want non-GAAP financial measures to be as reliable as GAAP number and present a similar comparable outlook for the firms, then assurance on the non-GAAP financial measures is the next logical step. Further, with a discussion on having assurance on the MD\&A, there is a potential to undertake experimental research which examines the audit implications and considerations.

There is potential to examine enforceability when it comes to guidance on reporting non-GAAP measures. Non-GAAP financial measures could be regulated only if the regulators have enforceability powers. An extension of this study is to do an institutional analysis in Canada. Following the adoption of NI 52-112, future studies can examine the impact of the regulatory intervention before and after enactment of a regulation, or by an event study.

There is scope to investigate non-GAAP financial measures in cross-listed and foreign listed firm in Canada and compare them to the findings of Entwistle et al. (2005), where they examine the behavior of non-GAAP financial measures of foreign-listed firms in the US. Examining non-GAAP financial measures in other parts of the world and various institutional studies could provide valuable insights. Furthermore, study in the area of non-GAAP financial measures could lead to more valuable findings if this study is replicated in other IFRS adopting emerging economies.

Christensen et al. (2014) and Bhattacharya et al. (2017), both find consistent results that short sellers perceive non-GAAP financial measures as an indication deteriorating performance and that the quality of 
reporting is subpar. This highlights the need to study if the earlier evidence still holds or if there are changes in the perceptions, usage, and behavior of analysts with respect to non-GAAP financial measures. Future research in Canada and around the world could study perceptions regarding non-GAAP among sophisticated and non-sophisticated stakeholders. Following, Choi and Young (2015) one can extend nonGAAP financial measures to examine the impact on analysts and investors. Survey-based research could be executed to capture retail investors position, stance, and understanding of non-GAAP financial measures.

Placement and position of non-GAAP financial measures were examined through experimental research by Frederickson and Miller (2004) and they suggest that there is positive an association between the behavior of investor and position of non-GAAP financial measure in a press release. Future research could be done examining the position of non-GAAP financial measures in the annual report and the behavior of naïve investors versus an analyst using more recent data.

Govendir and Wells (2013) examine the association of non-GAAP financial measures with stock returns for US-listed firm. They report a weak association of non-GAAP financial measures with stock returns. Since non-GAAP financial measures are not regulated, this potentially could be limiting the ability of the market to see through the non-GAAP financial measures and the level of confidence they have in non-GAAP financial measures. Future research could further examine whether there an association between higher quality disclosures of non-GAAP financial measures and the market value of firms' shares to assess whether information in the MD\&A and better disclosures are captured in the trading value of a company.

Most studies that have been looking at the press releases (Entwistle, 2005) and MD\&A. To further the understanding on non-GAAP financial measures, the extent to which market participants use the front end and preliminary matter in Annual Reports could be examined. This could be implemented through a survey administered to analysts or examined through experimental or field study.

Future research could look at the main inclusions and exclusions and differentiate opportunistic firms from the opportunistic ones. These exclusions and inclusions could also be used by standard setter to identify possible loopholes to fill with improved standards. Further studies are warranted in this area to study exclusions in different contexts, such as across countries, cultures, economic cycles, etc. 
Based on the findings of this study, it is imperative that detailed studies are further done to examine non-GAAP financial measures in a specific industry and to investigate the similarities and difference among different industry groups when reporting non-GAAP financial measures. Given the current direction of modification and changes in regulation of non-GAAP financial measures, examining non-GAAP financial measures individual industry in detail could provide further insights. There is potential to examine and propose the need for industry specific guidance with respect to non-GAAP financial measures.

An added benefit of this paper is the compilation of a database that reflects the current practice of firms when disclosing non-GAAP financial measures and the level of compliance with the existing guidelines. This database could be expanded to be used for future studies. With more data, an in-depth and detailed analysis of non-GAAP financial measures would be possible. 


\section{APPENDICES}

\section{APPENDIX A - DISTRIBUTION OF THE 74 REPORTED NON-GAAP FINANCIAL MEASURES}

OBSERVED IN STUDY'S SAMPLE

\begin{tabular}{|c|c|c|c|c|c|}
\hline S. No. & Reported non-GAAP Financial Measures & $\begin{array}{l}\text { Real } \\
\text { Estate } \\
\text { (Out of 24) }\end{array}$ & $\begin{array}{l}\text { Cannabis } \\
\text { (Out of } \\
\text { 10) }\end{array}$ & $\begin{array}{l}\text { Blockchain } \\
\text { / Crypto } \\
\text { (out of 9) }\end{array}$ & $\begin{array}{l}\text { No. \& (\%) } \\
\text { of } \\
\text { Companies } \\
\text { Reporting } \\
\text { (Out of 43) }\end{array}$ \\
\hline 1 & $\begin{array}{l}\text { Adjusted Earnings before Interest tax } \\
\text { Depreciation and Amortization (EBITDA) }\end{array}$ & $13(54.2 \%)$ & $7(70 \%)$ & $8(88.9 \%)$ & $28(65 \%)$ \\
\hline 2 & Funds from operations (FFO) & $22(91.7 \%)$ & - & - & $22(51 \%)$ \\
\hline 3 & Net Operating Income (NOI) & $17(70.8 \%)$ & - & - & $17(39 \%)$ \\
\hline 4 & Adjusted Funds from Operations (AFFO) & $14(58.3 \%)$ & - & - & $14(32 \%)$ \\
\hline 5 & Same Property Net Operating Income & $11(45.8 \%)$ & - & - & $11(25 \%)$ \\
\hline 6 & Interest Coverage & $9(37.5 \%)$ & - & - & $9(20 \%)$ \\
\hline 7 & Adjusted Cash Flows & $7(29.2 \%)$ & - & - & $7(16 \%)$ \\
\hline 8 & Free Cash flows & $4(16.7 \%)$ & $1(10 \%)$ & $1(11.1 \%)$ & $6(14 \%)$ \\
\hline 9 & $\begin{array}{l}\text { Earning Before Interest Taxes Depreciation and } \\
\text { Amortization (EBITDA) }\end{array}$ & $4(16.7 \%)$ & $1(10 \%)$ & - & $5(12 \%)$ \\
\hline 10 & Normalized Funds from Operation & $4(16.7 \%)$ & - & - & $4(9 \%)$ \\
\hline 11 & Adjusted Earnings Per Share (EPS) & $2(8.3 \%)$ & - & $2(22.2 \%)$ & $4(9 \%)$ \\
\hline 12 & Total leverage Ratio & $3(12.5 \%)$ & - & $1(11.1 \%)$ & $4(9 \%)$ \\
\hline 13 & Debt to Adjusted EBITDA & $4(16.7 \%)$ & - & - & $4(9 \%)$ \\
\hline 14 & Debt service coverage & $4(16.7 \%)$ & - & - & $4(9 \%)$ \\
\hline 15 & Proportionate interest & $4(16.7 \%)$ & - & - & $4(9 \%)$ \\
\hline 16 & Unencumbered assets to unsecured debt & $4(16.7 \%)$ & - & - & $4(9 \%)$ \\
\hline 17 & Adjusted Net profit & - & $2(20 \%)$ & $1(11.1 \%)$ & $3(7 \%)$ \\
\hline 18 & Adjusted Net Income & $1(4.2 \%)$ & - & $2(22.2 \%)$ & $3(7 \%)$ \\
\hline 19 & Adjusted Product Contribution & - & $3(30 \%)$ & - & $3(7 \%)$ \\
\hline 20 & Gross Profit & - & $1(10 \%)$ & $2(22.2 \%)$ & $3(7 \%)$ \\
\hline 21 & Adjusted Gross margin & - & $2(20 \%)$ & $1(11.1 \%)$ & $3(7 \%)$ \\
\hline 22 & Adjusted Earnings before Interest (EBIT) & - & $1(10 \%)$ & $2(22.2 \%)$ & $3(7 \%)$ \\
\hline 23 & Net Asset Value & $3(12.5 \%)$ & - & - & $3(7 \%)$ \\
\hline 24 & Net Debt & $1(4.2 \%)$ & - & $2(22.2 \%)$ & $3(7 \%)$ \\
\hline 25 & Weighted Average Cost per Gram & - & $3(30 \%)$ & - & $3(7 \%)$ \\
\hline 26 & Cash Cost to Produce & - & $3(30 \%)$ & - & $3(7 \%)$ \\
\hline 27 & Cash Flow & - & $1(10 \%)$ & $1(11.1 \%)$ & $2(5 \%)$ \\
\hline 28 & Working Capital & $1(4.2 \%)$ & - & $1(11.1 \%)$ & $2(5 \%)$ \\
\hline 29 & Net earnings excluding specific items & - & $1(10 \%)$ & $1(11.1 \%)$ & $2(5 \%)$ \\
\hline 30 & Comparative NOI & $2(8.3 \%)$ & - & - & $2(5 \%)$ \\
\hline
\end{tabular}




\begin{tabular}{|c|c|c|c|c|c|}
\hline S. No. & Reported non-GAAP Financial Measures & $\begin{array}{l}\text { Real } \\
\text { Estate } \\
\text { (Out of 24) }\end{array}$ & $\begin{array}{l}\text { Cannabis } \\
\text { (Out of } \\
\text { 10) }\end{array}$ & $\begin{array}{l}\text { Blockchain } \\
\text { / Crypto } \\
\text { (out of 9) }\end{array}$ & $\begin{array}{l}\text { No. \& (\%) } \\
\text { of } \\
\text { Companies } \\
\text { Reporting } \\
\text { (Out of 43) }\end{array}$ \\
\hline 31 & Estimated loss to lease & $2(8.3 \%)$ & - & - & $2(5 \%)$ \\
\hline 32 & Earnings per Share (EPS) & - & $1(10 \%)$ & $1(11.1 \%)$ & $2(5 \%)$ \\
\hline 33 & Entity/Enterprise Value Added (EVA) & $2(8.3 \%)$ & - & - & $2(5 \%)$ \\
\hline 34 & Return on Invested Capital (ROIC) & - & - & $2(22.2 \%)$ & $2(5 \%)$ \\
\hline 35 & Research and Development & - & - & $1(11.1 \%)$ & $1(2 \%)$ \\
\hline 36 & Non-GAAP Revenue & - & - & $1(11.1 \%)$ & $1(2 \%)$ \\
\hline 37 & Monthly recurring revenue & $1(4.2 \%)$ & - & - & $1(2 \%)$ \\
\hline 38 & Quarterly net yield & - & - & $1(11.1 \%)$ & $1(2 \%)$ \\
\hline 39 & Liquidity & - & - & $1(11.1 \%)$ & $1(2 \%)$ \\
\hline 40 & Non-Cash Working Capital & - & - & $1(11.1 \%)$ & $1(2 \%)$ \\
\hline 41 & Adjusted Net profit percentage & $1(4.2 \%)$ & - & - & $1(2 \%)$ \\
\hline 42 & Adjusted net income margin & $1(4.2 \%)$ & - & - & $1(2 \%)$ \\
\hline 43 & Adjusted Net Operating Income (NOI) & - & - & $1(11.1 \%)$ & $1(2 \%)$ \\
\hline 44 & NOI from unencumbered Assets & $1(4.2 \%)$ & - & - & $1(2 \%)$ \\
\hline 45 & Gross Profit per share & - & - & $1(11.1 \%)$ & $1(2 \%)$ \\
\hline 46 & Consolidated EBITDA & $1(4.2 \%)$ & - & - & $1(2 \%)$ \\
\hline 47 & Adjusted EBITDA Margin & $1(4.2 \%)$ & - & - & $1(2 \%)$ \\
\hline 48 & $\begin{array}{l}\text { European Public Real Estate Association } \\
\text { (EPRA) Earnings }\end{array}$ & $1(4.2 \%)$ & - & - & $1(2 \%)$ \\
\hline 49 & Adjusted EPRA Earnings & $1(4.2 \%)$ & - & - & $1(2 \%)$ \\
\hline 50 & $\begin{array}{l}\text { European Public Real Estate Association Net } \\
\text { Asset Value (EPRA NAV) }\end{array}$ & - & - & $1(11.1 \%)$ & $1(2 \%)$ \\
\hline 51 & $\begin{array}{l}\text { European Public Real Estate Association Triple } \\
\text { Net Asset Value (EPRA NNNAV) }\end{array}$ & - & - & $1(11.1 \%)$ & $1(2 \%)$ \\
\hline 52 & Adjusted Earnings & $1(4.2 \%)$ & - & - & $1(2 \%)$ \\
\hline 53 & $\begin{array}{l}\text { Basic and diluted earnings per share excluding } \\
\text { specific items }\end{array}$ & - & - & $1(11.1 \%)$ & $1(2 \%)$ \\
\hline 54 & Unencumbered Assets & - & - & $1(11.1 \%)$ & $1(2 \%)$ \\
\hline 55 & Gross Book Value & $1(4.2 \%)$ & - & - & $1(2 \%)$ \\
\hline 56 & Return on Equity & $1(4.2 \%)$ & - & - & $1(2 \%)$ \\
\hline 57 & Capital employed & $1(4.2 \%)$ & - & - & $1(2 \%)$ \\
\hline 58 & Debt to Gross Book Value & $1(4.2 \%)$ & - & - & $1(2 \%)$ \\
\hline 59 & Indebtedness Ratio & $1(4.2 \%)$ & - & - & $1(2 \%)$ \\
\hline 60 & Consolidated Interest Expense & $1(4.2 \%)$ & - & - & $1(2 \%)$ \\
\hline 61 & Non-Consolidated Indebtedness & - & - & $1(11.1 \%)$ & $1(2 \%)$ \\
\hline 62 & Nonconsolidated interest Charge & - & - & $1(11.1 \%)$ & $1(2 \%)$ \\
\hline
\end{tabular}




\begin{tabular}{|c|c|c|c|c|c|}
\hline S. No. & Reported non-GAAP Financial Measures & $\begin{array}{l}\text { Real } \\
\text { Estate } \\
\text { (Out of 24) }\end{array}$ & $\begin{array}{l}\text { Cannabis } \\
\text { (Out of } \\
\text { 10) }\end{array}$ & $\begin{array}{l}\text { Blockchain } \\
\text { / Crypto } \\
\text { (out of 9) }\end{array}$ & $\begin{array}{l}\text { No. \& (\%) } \\
\text { of } \\
\text { Companies } \\
\text { Reporting } \\
\text { (Out of } 43 \text { ) }\end{array}$ \\
\hline 63 & Fixed Charge coverage & - & - & $1(11.1 \%)$ & $1(2 \%)$ \\
\hline 64 & Foreign Exchange Effects & - & - & $1(11.1 \%)$ & $1(2 \%)$ \\
\hline 65 & Utilization & - & - & $1(11.1 \%)$ & $1(2 \%)$ \\
\hline 66 & Billing retention & - & - & $1(11.1 \%)$ & $1(2 \%)$ \\
\hline 67 & Backlog & - & - & $1(11.1 \%)$ & $1(2 \%)$ \\
\hline 68 & Gross merchandise Volume & - & - & $1(11.1 \%)$ & $1(2 \%)$ \\
\hline 69 & Days Sales Outstanding & - & $1(10 \%)$ & - & $1(2 \%)$ \\
\hline 70 & Constant Currency growth & - & - & $1(11.1 \%)$ & $1(2 \%)$ \\
\hline 71 & Book to Bills Ratio & - & - & $1(11.1 \%)$ & $1(2 \%)$ \\
\hline 72 & Baseline Revenue & - & - & $1(11.1 \%)$ & $1(2 \%)$ \\
\hline 73 & Baseline Calibration & - & - & $1(11.1 \%)$ & $1(2 \%)$ \\
\hline 74 & Nonconsolidated Shareholders Equity & - & - & $1(11.1 \%)$ & $1(2 \%)$ \\
\hline
\end{tabular}




\section{APPENDIX B - TABLES OF ADJUSTMENTS TO SELECTED COMMON NON-GAAP FINANCIAL MEASURES}

\section{Adjusted Earning Before Interest Tax and Amortization}

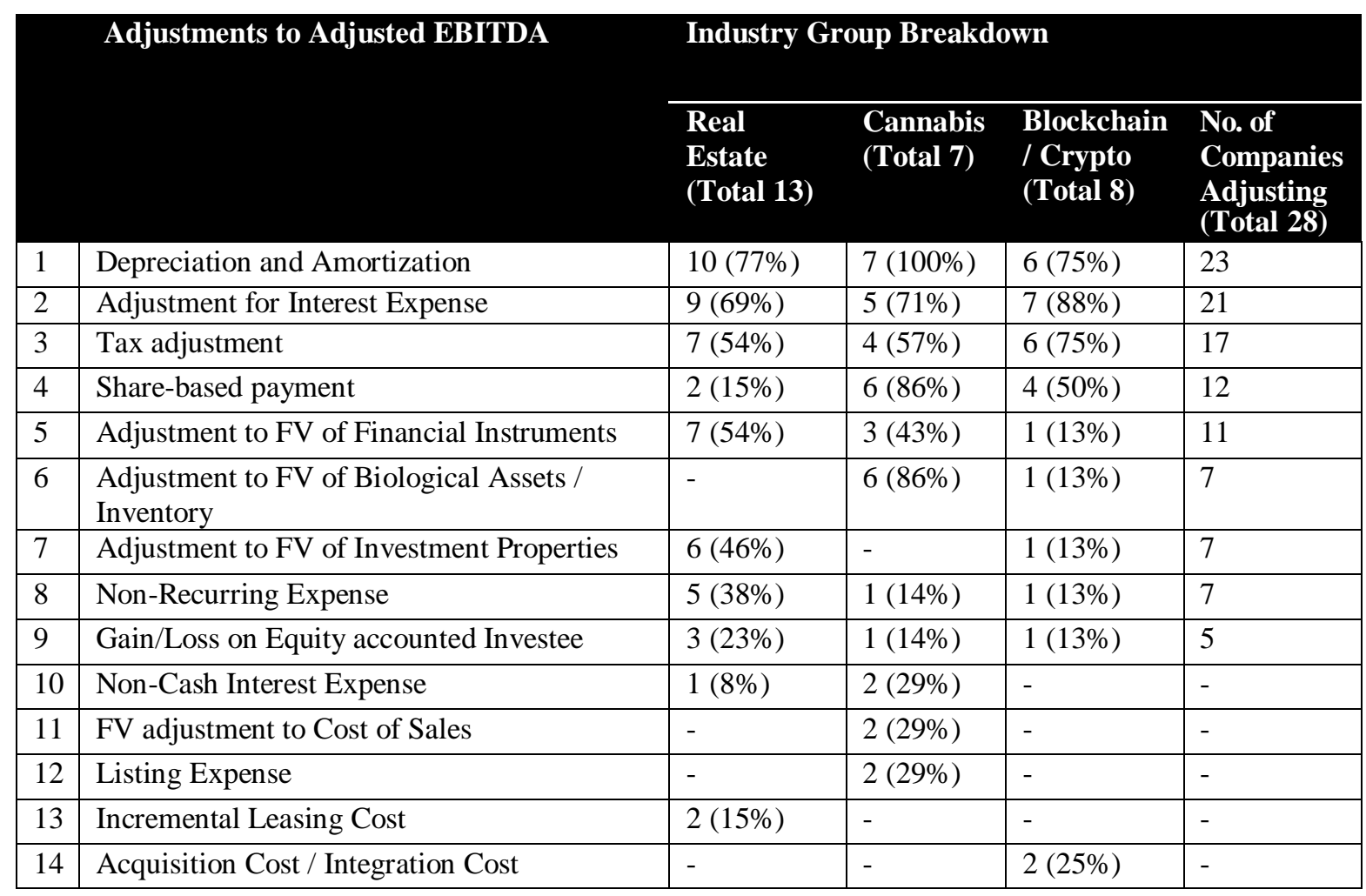

\section{Free Cash Flows}

\begin{tabular}{|c|c|c|c|c|c|}
\hline \multicolumn{2}{|r|}{ Adjustments to Free Cash Flows } & \multicolumn{4}{|c|}{ Industry Group Breakdown } \\
\hline & & $\begin{array}{l}\text { Real } \\
\text { Estate } \\
\text { (Total 4) }\end{array}$ & $\begin{array}{l}\text { Cannabis } \\
\text { (Total 1) }\end{array}$ & $\begin{array}{l}\text { Blockchain } \\
\text { / Crypto } \\
\text { (Total 1) }\end{array}$ & $\begin{array}{l}\text { No. of } \\
\text { Companies } \\
\text { Adjusting } \\
\text { (Total 6) }\end{array}$ \\
\hline 1 & Capex & $4(100 \%)$ & - & $1(100 \%)$ & 5 \\
\hline 2 & Investment in other assets & $3(75 \%)$ & $1(100 \%)$ & $1(100 \%)$ & 6 \\
\hline 3 & Proceeds from disposal of PPE & $4(100 \%)$ & - & - & 4 \\
\hline 4 & Dividends & $2(50 \%)$ & $1(100 \%)$ & - & 3 \\
\hline
\end{tabular}




\section{Funds from Operations}

\begin{tabular}{|l|l|l|}
\hline \multicolumn{2}{|c|}{ Adjustment to Funds from operations } & $\begin{array}{l}\text { No. and (\%) of RE } \\
\text { Companies Adjusting } \\
\text { (Total 22) }\end{array}$ \\
\hline \multicolumn{2}{|l|}{} \\
\hline 1 & FV adjustments - Investment Properties & $17(77 \%)$ \\
\hline 2 & Amortization / Depreciation & $17(77 \%)$ \\
\hline 3 & Gain/Loss on Sale or Acquisition / Investment Properties & $16(72 \%)$ \\
\hline 4 & FV adjustment - Financial Instruments & $13(60 \%)$ \\
\hline 5 & Income Tax / Deferred Taxes & $12(54 \%)$ \\
\hline 6 & Acquisition Costs & $7(31 \%)$ \\
\hline 7 & Distribution on Limited Partnership Units & $4(18 \%)$ \\
\hline 8 & Interest Expense & $3(13 \%)$ \\
\hline 9 & FX Gain / Loss & $2(9 \%)$ \\
\hline 10 & Adjustments for Joint Venture Accounting & $2(9 \%)$ \\
\hline 11 & Non-recurring insurance settlements & $2(9 \%)$ \\
\hline 12 & Goodwill derecognition & $1(5 \%)$ \\
\hline 13 & Debt Settlement Cost & $1(5 \%)$ \\
\hline
\end{tabular}

\section{Net Operating Income}

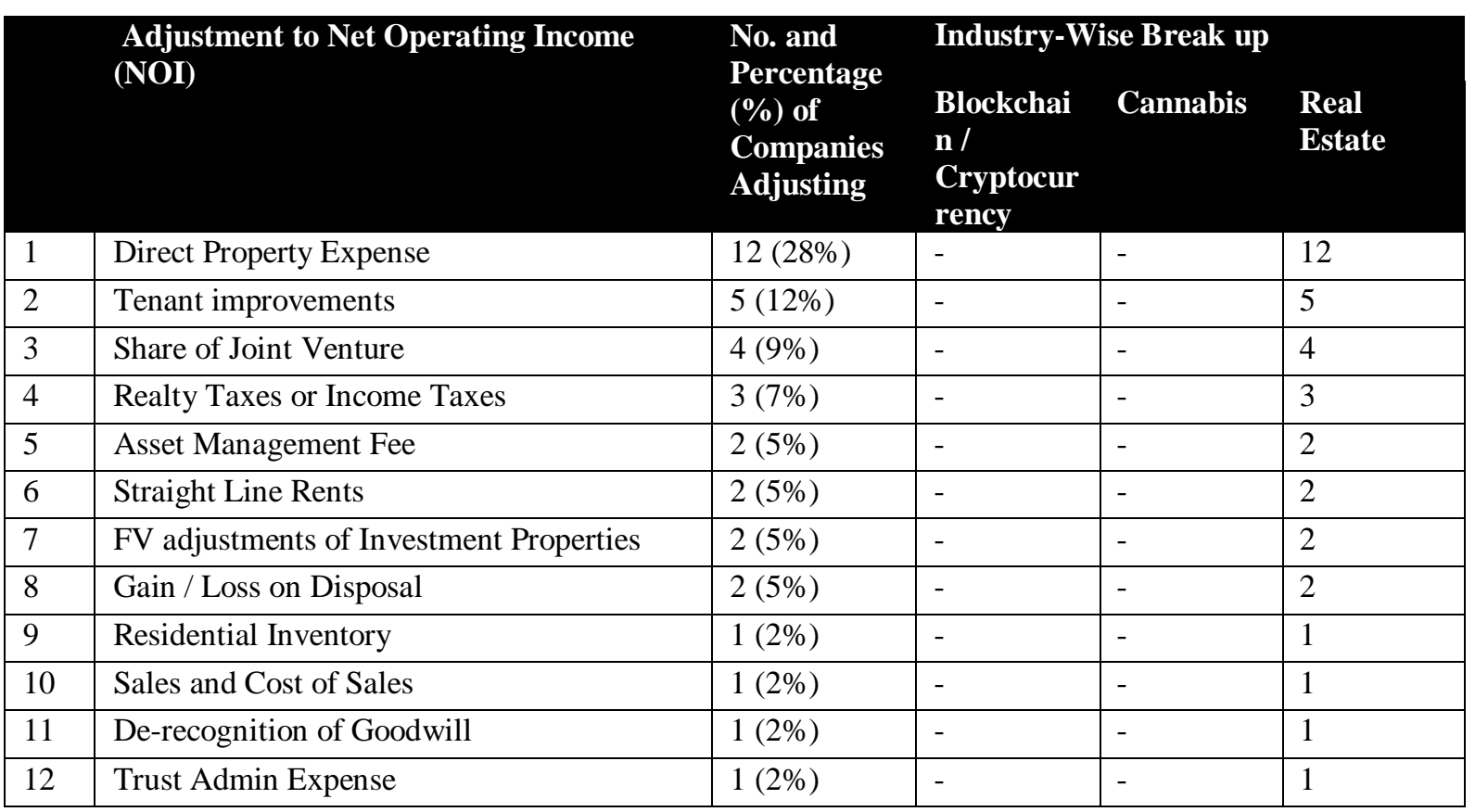




\section{Cash Cost to Produce}

\begin{tabular}{|l|l|l|}
\hline \multicolumn{2}{|c|}{ Adjustment to Cash Cost to Produce } & $\begin{array}{l}\text { No. and Percentage (\%) of } \\
\text { Cannabis Companies Adjusting } \\
\text { (Total 3) }\end{array}$ \\
\hline 1 & FV of Biological Assets & $2(67 \%)$ \\
\hline 2 & Post production cost & $1(33 \%)$ \\
\hline
\end{tabular}

\section{Adjusted Product Contribution}

\begin{tabular}{|l|l|l|}
\hline \multicolumn{2}{|c|}{$\begin{array}{l}\text { Adjustment to Adjusted Product } \\
\text { Contribution }\end{array}$} & $\begin{array}{l}\text { No. and Percentage (\%) of } \\
\text { Cannabis Companies Adjusting } \\
\text { (Total 3) }\end{array}$ \\
\hline 1 & FV of Biological Assets & $3(75 \%)$ \\
\hline 2 & Inventory write-downs & $1(25 \%)$ \\
\hline
\end{tabular}

\section{Adjusted Funds from Operations}

\begin{tabular}{|c|c|c|c|c|c|}
\hline \multirow[t]{2}{*}{ S. No. } & \multirow[t]{2}{*}{ Adjustments to Adjusted FFO } & \multirow{2}{*}{$\begin{array}{l}\text { No. and } \\
\text { Percentage (\%) } \\
\text { of Companies } \\
\text { Adjusting }\end{array}$} & \multicolumn{3}{|c|}{ Industry-Wise Break up } \\
\hline & & & $\begin{array}{l}\text { Blockchain / } \\
\text { Cryptocurrency }\end{array}$ & Cannabis & $\begin{array}{l}\text { Real } \\
\text { Estate }\end{array}$ \\
\hline 1 & Amortize Straight Line (SL) Rent & $6(14 \%)$ & - & - & 6 \\
\hline 2 & Capex & $6(14 \%)$ & - & - & 6 \\
\hline 3 & Leasing activities cost & $6(14 \%)$ & - & - & 6 \\
\hline 4 & Amortize Financing Cost & $3(7 \%)$ & - & - & 3 \\
\hline 5 & Maintenance Cost & $3(7 \%)$ & - & - & 3 \\
\hline 6 & Non-Cash Items & $2(5 \%)$ & - & - & 2 \\
\hline 7 & Lease Expense & $2(5 \%)$ & - & - & 2 \\
\hline 8 & Deferred Unit Compensation & $2(5 \%)$ & - & - & 2 \\
\hline 9 & Deferred Asset Mgmt. Fee & $2(5 \%)$ & - & - & 2 \\
\hline 10 & Swap Agreement and Settlement & $1(2 \%)$ & - & - & 1 \\
\hline
\end{tabular}




\section{Same Property Net Operating Income}

\begin{tabular}{|c|c|c|c|c|c|}
\hline \multirow[t]{2}{*}{ S. No. } & \multirow[t]{2}{*}{ Adjustments to Same Property NOI } & \multirow{2}{*}{$\begin{array}{l}\text { No. and } \\
\text { Percentage } \\
(\%) \text { of } \\
\text { Companies } \\
\text { Adjusting }\end{array}$} & \multicolumn{3}{|c|}{ Industry-Wise Break up } \\
\hline & & & $\begin{array}{l}\text { Blockchain / } \\
\text { Cryptocurrency }\end{array}$ & Cannabis & $\begin{array}{l}\text { Real } \\
\text { Estate }\end{array}$ \\
\hline 1 & Remove Non-recurring NOI from assets & $6(14 \%)$ & - & - & 6 \\
\hline 2 & Annualized rental income & $2(5 \%)$ & - & - & 2 \\
\hline 3 & Remove impact of Cancellation Fee and SL Revenue & $1(2 \%)$ & - & - & 1 \\
\hline 4 & Less Property Specific Cost & $1(2 \%)$ & - & - & 1 \\
\hline 5 & Earnouts net of service and other revenues & $1(2 \%)$ & - & - & 1 \\
\hline 6 & Income and Expense for stable properties & $1(2 \%)$ & - & - & 1 \\
\hline
\end{tabular}

\section{Interest Coverage Ratio}

\begin{tabular}{|c|c|c|c|c|c|}
\hline \multirow[t]{2}{*}{ S. No. } & \multirow[t]{2}{*}{ Calculation of Interest Coverage Ratio } & \multirow{2}{*}{$\begin{array}{l}\text { No. and } \\
\text { Percentage (\%) } \\
\text { of Companies } \\
\text { Adjusting }\end{array}$} & \multicolumn{3}{|c|}{ Industry-Wise Break up } \\
\hline & & & $\begin{array}{l}\text { Blockchain / } \\
\text { Cryptocurrency }\end{array}$ & Cannabis & $\begin{array}{l}\text { Real } \\
\text { Estate }\end{array}$ \\
\hline 1 & EBITDA/ Interest Expense & $8(16 \%)$ & - & - & 8 \\
\hline 2 & EBITDA/ Capitalized interest Expense & $1(2 \%)$ & - & - & 1 \\
\hline
\end{tabular}

\section{Adjusted Cash Flows}

\begin{tabular}{|c|c|c|c|c|c|}
\hline \multirow{2}{*}{$\begin{array}{l}\text { S. } \\
\text { No. }\end{array}$} & \multirow{2}{*}{$\begin{array}{l}\text { Adjustments to Adjusted Cash } \\
\text { Flows }\end{array}$} & \multirow{2}{*}{$\begin{array}{l}\text { No. of Companies } \\
\text { Adjusting }\end{array}$} & \multicolumn{3}{|c|}{ Industry-Wise Break up } \\
\hline & & & $\begin{array}{l}\text { Blockchain / } \\
\text { Cryptocurrency }\end{array}$ & Cannabis & $\begin{array}{l}\text { Real } \\
\text { Estate }\end{array}$ \\
\hline 1 & Change in Working Capital & $5(12 \%)$ & - & - & 5 \\
\hline 2 & Amortization of Finance Cost & $4(9 \%)$ & - & - & 4 \\
\hline 3 & Maintenance Cost & $3(7 \%)$ & - & - & 3 \\
\hline 4 & Leasing Cost & $2(5 \%)$ & - & - & 2 \\
\hline 5 & Joint Venture Amounts & $2(5 \%)$ & - & - & 2 \\
\hline 6 & Insurance & $2(5 \%)$ & - & - & 2 \\
\hline 7 & Grants & $2(5 \%)$ & - & - & 2 \\
\hline 8 & Income Taxes & $1(2 \%)$ & - & - & 1 \\
\hline 9 & Non-Cash interest expense & $1(2 \%)$ & - & - & 1 \\
\hline 10 & Amortization of FV Adjustment & $1(2 \%)$ & - & - & 1 \\
\hline 11 & Capex & $1(2 \%)$ & - & - & 1 \\
\hline 12 & Transaction cost & $1(2 \%)$ & - & - & 1 \\
\hline
\end{tabular}




\section{Earnings Before Interest Tax Depreciation and Amortization}

\begin{tabular}{|c|c|c|c|c|c|}
\hline \multirow[t]{2}{*}{ S. No. } & \multirow[t]{2}{*}{ Adjustments to EBITDA } & \multirow{2}{*}{$\begin{array}{l}\text { No. of } \\
\text { Companies } \\
\text { Adjusting }\end{array}$} & \multicolumn{3}{|c|}{ Industry-Wise Break up } \\
\hline & & & $\begin{array}{l}\text { Blockchain/ } \\
\text { Cryptocurrency }\end{array}$ & Cannabis & $\begin{array}{l}\text { Real } \\
\text { Estate }\end{array}$ \\
\hline 1 & Interest Expense & $5(12 \%)$ & - & 1 & 4 \\
\hline 2 & Income Tax Expense & $4(9 \%)$ & - & 1 & 3 \\
\hline 3 & Dep and Amortization & $4(9 \%)$ & - & 1 & 3 \\
\hline 4 & Gain/Loss on Disposal & $2(5 \%)$ & - & - & 2 \\
\hline 5 & Gain/Loss on Equity accounted Investee & $2(5 \%)$ & - & - & 2 \\
\hline 6 & Non-Cash Revenue and Expense & $1(2 \%)$ & - & - & 1 \\
\hline
\end{tabular}


APPENDIX C - LIST OF SAMPLE FIRMS

\begin{tabular}{|c|c|c|c|c|c|}
\hline & Company Name & Ticker & $\begin{array}{l}\text { Industry } \\
\text { Group }\end{array}$ & $\begin{array}{l}\text { Market } \\
\text { Capitalization }\end{array}$ & $\begin{array}{l}\text { Discloser of } \\
\text { Non-GAAP } \\
\text { measure }\end{array}$ \\
\hline 1 & $\begin{array}{l}\text { ABcann Global } \\
\text { Corporation }\end{array}$ & $\mathrm{ABCN}$ & Cannabis & $87,655,342$ & No \\
\hline 2 & Canabo Medical Inc. & CMM & Cannabis & $26,194,098$ & No \\
\hline 3 & Cronos Group Inc. & MJN & Cannabis & $1,434,546,092$ & No \\
\hline 4 & Delta 9 Cannabis Inc. & NINE & Cannabis & $72,681,349$ & No \\
\hline 5 & $\begin{array}{l}\text { Emerald Health } \\
\text { Therapeutics, Inc. }\end{array}$ & EMH & Cannabis & $403,023,473$ & No \\
\hline 6 & Harvest One Cannabis Inc. & HVST & Cannabis & $44,788,852$ & No \\
\hline 7 & ICC Labs, Inc. & ICC & Cannabis & $115,016,121$ & No \\
\hline 8 & INDIVA Limited & NDVA & Cannabis & $53,119,632$ & No \\
\hline 9 & Kalytera Therapeutics Inc. & KALY & Cannabis & $56,355,406$ & No \\
\hline 10 & $\begin{array}{l}\text { Maple Leaf Green World } \\
\text { Inc. }\end{array}$ & MGW & Cannabis & $110,304,998$ & No \\
\hline 11 & Newstrike Resources Ltd. & HIP & Cannabis & $218,139,234$ & No \\
\hline 12 & Scythian Biosciences Corp. & SCYB & Cannabis & $53,104,058$ & No \\
\hline 13 & Tetra Bio-Pharma Inc. & TBP & Cannabis & $129,615,485$ & No \\
\hline 14 & $\begin{array}{l}\text { The Supreme Cannabis } \\
\text { Company, Inc. }\end{array}$ & FIRE & Cannabis & $490,719,415$ & No \\
\hline 15 & LiveWell Canada Inc. & LVWL & Cannabis & $175,985,888$ & No \\
\hline 16 & Emblem Corp. & EMC & Cannabis & $160,667,063$ & Yes \\
\hline 17 & $\begin{array}{l}\text { Hydropothecary } \\
\text { Corporation (The) }\end{array}$ & THCX & Cannabis & $368,483,049$ & Yes \\
\hline 18 & $\begin{array}{l}\text { National Access Cannabis } \\
\text { Corp. }\end{array}$ & NAC & Cannabis & $41,467,657$ & Yes \\
\hline 19 & OrganiGram Holdings Inc. & OGI & Cannabis & $494,281,293$ & Yes \\
\hline 20 & WeedMD Inc. & WMD & Cannabis & $146,036,734$ & Yes \\
\hline 21 & Aphria Inc. & $\mathrm{APH}$ & Cannabis & $2,839,992,319$ & Yes \\
\hline 22 & Aurora Cannabis Inc. & ACB & Cannabis & $4,346,237,789$ & Yes \\
\hline 23 & $\begin{array}{l}\text { CanniMed Therapeutics } \\
\text { Inc. }\end{array}$ & CMED & Cannabis & $550,973,441$ & Yes \\
\hline 24 & Canopy Growth Corp & WEED & Cannabis & $5,704,408,017$ & Yes \\
\hline 25 & MedReleaf Corp. & LEAF & Cannabis & $2,009,924,229$ & Yes \\
\hline 26 & BlockchainK2 Corp. & BITK & Crypto & $24,770,488$ & No \\
\hline 27 & $\begin{array}{l}\text { Boardwalktech Software } \\
\text { Corp. }\end{array}$ & yes & Crypto & $5,440,036$ & Yes \\
\hline 28 & BTL Group Ltd. & BTL & Crypto & $195,787,570$ & No \\
\hline
\end{tabular}




\begin{tabular}{|c|c|c|c|c|c|}
\hline & Company Name & Ticker & $\begin{array}{l}\text { Industry } \\
\text { Group }\end{array}$ & $\begin{array}{l}\text { Market } \\
\text { Capitalization }\end{array}$ & $\begin{array}{l}\text { Discloser of } \\
\text { Non-GAAP } \\
\text { measure }\end{array}$ \\
\hline 29 & $\begin{array}{l}\text { DMG Blockchain } \\
\text { Solutions Inc./Aim } \\
\text { Explorations }\end{array}$ & yes & Crypto & $1,581,940$ & No \\
\hline 30 & Fortress Blockchain Corp. & yes & Crypto & $7,895,468$ & No \\
\hline 31 & $\begin{array}{l}\text { HashChain Technology } \\
\text { Inc. }\end{array}$ & KASH & Crypto & $120,248,100$ & No \\
\hline 32 & $\begin{array}{l}\text { HIVE Blockchain } \\
\text { Technologies Ltd. }\end{array}$ & HIVE & Crypto & $587,082,782$ & Yes \\
\hline 33 & Hut 8 Mining Corp. & HUT & Crypto & $243,465,420$ & Yes \\
\hline 34 & $\begin{array}{l}\text { iMining Blockchain and } \\
\text { Cryptocurrency Inc. }\end{array}$ & yes & Crypto & $2,617,764$ & No \\
\hline 35 & $\begin{array}{l}\text { Neptune Dash } \\
\text { Technologies Corp. }\end{array}$ & DASH & Crypto & $9,623,199$ & No \\
\hline 36 & Interbit Ltd. & IBIT & Crypto & $97,506,753$ & No \\
\hline 37 & FluroTech Ltd. & TEST & Crypto & $24,384,054$ & No \\
\hline 38 & $\begin{array}{l}\text { Voyager Digital (Canada) } \\
\text { Ltd. }\end{array}$ & VYGR & Crypto & $20,156,477$ & No \\
\hline 39 & iLOOKABOUT Corp. & ILA & Crypto & $17,002,357$ & Yes \\
\hline 40 & Globalive Technology Inc. & yes & Crypto & $60,075,933$ & No \\
\hline 41 & LeoNovus Inc. & LTV & Crypto & $77,288,004$ & Yes \\
\hline 42 & Fintech Select Ltd. & FTEC & Crypto & $8,834,981$ & No \\
\hline 43 & Cryptostar Corp. & CSTR & Crypto & $3,131,292$ & Yes \\
\hline 44 & $\begin{array}{l}\text { Datable Technology } \\
\text { Corporation }\end{array}$ & $\mathrm{DAC}$ & Crypto & $3,709,006$ & Yes \\
\hline 45 & Fireswirl Technologies Inc. & FSW & Crypto & 214,050 & Yes \\
\hline 46 & $\begin{array}{l}\text { Global Blockchain } \\
\text { Technologies Corp. }\end{array}$ & BLOC & Crypto & $59,999,336$ & No \\
\hline 47 & $\begin{array}{l}\text { Galaxy Digital Holdings } \\
\text { Ltd./Bradmer }\end{array}$ & GLXY & Crypto & $146,089,481$ & No \\
\hline 48 & $\begin{array}{l}\text { Skychain Technologies } \\
\text { Inc. }\end{array}$ & SCT & Crypto & $1,659,634$ & No \\
\hline 49 & Mobio Technologies Inc. & $\mathrm{MBO}$ & Crypto & $2,336,662$ & No \\
\hline 50 & COIN Hodl Inc./Malbex & COIN & Crypto & $5,642,071$ & No \\
\hline
\end{tabular}




\begin{tabular}{|c|c|c|c|c|c|}
\hline & Company Name & Ticker & $\begin{array}{l}\text { Industry } \\
\text { Group }\end{array}$ & $\begin{array}{l}\text { Market } \\
\text { Capitalization }\end{array}$ & $\begin{array}{l}\text { Discloser of } \\
\text { Non-GAAP } \\
\text { measure }\end{array}$ \\
\hline 51 & $\begin{array}{l}\text { Riocan Real Estate } \\
\text { Investment Trust }\end{array}$ & REI & Real Estate & $7,892,066,493$ & Yes \\
\hline 52 & $\begin{array}{l}\text { Brookfield Property } \\
\text { Partners L.P. }\end{array}$ & BPY & Real Estate & $7,100,026,865$ & Yes \\
\hline 53 & $\begin{array}{l}\text { H\&R Real Estate } \\
\text { Investment Trust }\end{array}$ & HR & Real Estate & $6,332,059,139$ & Yes \\
\hline 54 & $\begin{array}{l}\text { Canadian Apartment } \\
\text { Properties Real Estate } \\
\text { Investment Trust }\end{array}$ & CAR & Real Estate & $5,131,162,179$ & Yes \\
\hline 55 & First Capital Realty Inc. & FCR & Real Estate & $5,112,970,507$ & Yes \\
\hline 56 & $\begin{array}{l}\text { CT Real Estate Investment } \\
\text { Trust }\end{array}$ & CRT & Real Estate & $4,132,138,002$ & Yes \\
\hline 57 & $\begin{array}{l}\text { SmartCentres Real Estate } \\
\text { Investment Trust }\end{array}$ & SRU & Real Estate & $3,902,259,386$ & Yes \\
\hline 58 & $\begin{array}{l}\text { Allied Properties Real } \\
\text { Estate Investment Trust }\end{array}$ & $\mathrm{AP}$ & Real Estate & $3,424,340,293$ & Yes \\
\hline 59 & $\begin{array}{l}\text { Chartwell Retirement } \\
\text { Residences }\end{array}$ & $\mathrm{CSH}$ & Real Estate & $3,397,450,663$ & Yes \\
\hline 60 & $\begin{array}{l}\text { Canadian Real Estate } \\
\text { Investment Trust }\end{array}$ & REF & Real Estate & $3,041,230,338$ & Yes \\
\hline 61 & FirstService Corporation & FSV & Real Estate & $2,865,183,195$ & Yes \\
\hline 62 & $\begin{array}{l}\text { Brookfield Business } \\
\text { Partners L.P. }\end{array}$ & BBU & Real Estate & $2,852,975,041$ & Yes \\
\hline 63 & $\begin{array}{l}\text { Colliers International } \\
\text { Group Inc. }\end{array}$ & CIGI & Real Estate & $2,667,361,147$ & Yes \\
\hline 64 & $\begin{array}{l}\text { Cominar Real Estate } \\
\text { Investment Trust }\end{array}$ & CUF & Real Estate & $2,552,402,057$ & Yes \\
\hline 65 & Gazit-Globe Ltd. & GZT & Real Estate & $2,438,231,071$ & Yes \\
\hline 66 & $\begin{array}{l}\text { Artis Real Estate } \\
\text { Investment Trust }\end{array}$ & $\mathrm{AX}$ & Real Estate & $2,309,987,624$ & Yes \\
\hline 67 & $\begin{array}{l}\text { Granite Real Estate } \\
\text { Investment Trust }\end{array}$ & GRT & Real Estate & $2,152,084,204$ & Yes \\
\hline 68 & $\begin{array}{l}\text { Dream Global Real Estate } \\
\text { Investment Trust }\end{array}$ & DRG & Real Estate & $2,125,317,086$ & Yes \\
\hline 69 & Morguard Corporation & MRC & Real Estate & $2,070,809,076$ & Yes \\
\hline 70 & $\begin{array}{l}\text { Pure Industrial Real Estate } \\
\text { Trust }\end{array}$ & AAR & Real Estate & $1,988,073,234$ & Yes \\
\hline 71 & $\begin{array}{l}\text { Boardwalk Real Estate } \\
\text { Investment Trust }\end{array}$ & BEI & Real Estate & $1,305,375,310$ & Yes \\
\hline
\end{tabular}




\begin{tabular}{|l|l|l|l|l|l|}
\hline \multicolumn{2}{|c}{ Company Name } & Ticker & \multicolumn{1}{l}{$\begin{array}{l}\text { Industry } \\
\text { Group }\end{array}$} & $\begin{array}{l}\text { Market } \\
\text { Capitalization }\end{array}$ & $\begin{array}{l}\text { Discloser of } \\
\text { Non-GAAP } \\
\text { measure }\end{array}$ \\
\hline 72 & $\begin{array}{l}\text { Crombie Real Estate } \\
\text { Investment Trust }\end{array}$ & CRR & Real Estate & $1,302,764,857$ & Yes \\
\hline 73 & $\begin{array}{l}\text { Northview Apartment Real } \\
\text { Estate Investment Trust }\end{array}$ & NVU & Real Estate & $1,256,917,839$ & Yes \\
\hline 74 & $\begin{array}{l}\text { Choice Properties Real } \\
\text { Estate Investment Trust }\end{array}$ & CHP & Real Estate & $1,144,493,401$ & Yes \\
\hline 75 & $\begin{array}{l}\text { Killam Apartment Real } \\
\text { Estate Investment Trust }\end{array}$ & KMP & Real Estate & $7,892,066,493$ & Yes \\
\hline
\end{tabular}




\section{APPENDIX D - SAMPLE MANAGEMENT DisCuSSION AND ANALYSIS DisClOSURE SCORING}

1. "Does the company identify and specify the purpose of the reported performance measure

2. Does the company explain why the chosen performance measure is relevant to the understanding of the strategy, objectives and goals of the entity measure?

3. Does the company define the performance measure?

4. Does the company explain the key methodologies and assumptions including components of the performance measure and how it is calculated?

5. Does the company clearly explain how the reported performance measure affects compensation payouts?

6. Does the company provide targets (past and future) for a performance measure?

7. Does the company provide how performance is tracking against that target?

8. Does the company provide trend data and explain management's actions given those trends

9. Does the company refer to an industry or sector-specific performance measure?

10. Does the company indicate whether a common definition is used, and, if not, how the definition 0 used differs?

11. Does the company provide a performance measure at the appropriate level of aggregation and disaggregation to enable users to understand the information?

12. Does the company specify source of the performance measure?

13. Does the company specify assumptions of the performance measure?

14. Does the company specify limitations of the performance measure

15. Does the company use meaningful labels that are clear and

16. The company does not describe as non-recurring, infrequent or unusual if it has occurred in recent years or is likely to occur in the near future.

17. Does the company explain the rationale for the adjustments to a GAAP financial measure

18. Does the company explain why the non-GAAP measure is more useful

19. Is a GAAP financial measure is reported equally prominent to a non-GAAP financial measure?

20. Does the company include a reconciliation of a non-GAAP financial measure to GAAP in the annual report?

21. Does the company clearly explain why a new performance measure is introduced and/or old performance measure is modified?

22. Explain why the new or a modified performance measure is more relevant.

23. Does the company state that it has developed and reported a performance measure following AcSB Framework or CSA guidelines?

24. Does the company state that a performance measure is unaudited, unless noted"

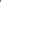

0




\section{REFERENCES}

Accounting Standards Board (AcSB). (2018). Draft Framework for Reporting Performance Measures. Financial Reporting \& Assurance Standards Canada, Chartered Professional Accountants of Canada, Toronto. http://www.frascanada.ca/accounting-standards-board/ Accessed June 23, 2018

Accounting Standards Board (AcSB). (2018, October 17). Comments on the draft framework for reporting performance measures. Retrieved from http://www.frascanada.ca/accounting-standardsboard/item86539.pdf. Accessed Nov 21, 2018

Adkerson, R. C. (1978). Discussion of DAAM: the demand for alternative accounting measurements. Journal of Accounting Research, 31-36.

Akerlof George, A. (1970). The Market for "Lemons": Quality Uncertainty and the Market Mechanism. Quarterly Journal of Economics, 84(1), 488-500.

Albring, S. M., Cabán-García, M. T., \& Reck, J. L. (2010). The value relevance of a non-GAAP pro forma earnings information? The Accounting Review, 82(3), 581-619.

Allee, K. D., Bhattacharya, N., Black, E. L., \& Christensen, T. E. (2007). Pro forma disclosure and investor sophistication: External validation of experimental evidence using archival data. Accounting, Organizations and Society, 32(3), 201-222.

Andersson, P., \& Hellman, N. (2007). Does pro forma reporting bias analyst forecasts? European Accounting Review, 16(2), 277-298.

Barth, M. E., Landsman, W. R., Lang, M., \& Williams, C. (2012). Are IFRS-based and US GAAP-based accounting amounts comparable? Journal of Accounting and Economics, 54(1), 68-93.

Batta, G., \& Muslu, V. (2017). Credit Rating Agency and Equity Analysts' Adjustments to GAAP Earnings. Contemporary Accounting Research, 34(2), 783-817.

Bentley, J. W., Christensen, T. E., Gee, K. H., \& Whipple, B. C. (2018). Disentangling Managers' and Analysts' Non-GAAP Reporting. Journal of Accounting Research, 56(4), 1039 - 1081.

Bewley, K., \& Magness, V. (2008). The impact of a change in regulation on environmental disclosure: SAB92 and the US chemical industry. Issues in Social and Environmental Accounting, 2(1), 6188.

Bhattacharya, N., Black, E., T., \& Larson, C. (2003). Assessing the relative informativeness and permanence of pro forma earnings and GAAP operating earnings. Journal of Accounting and Economics, (36), 285-319.

Bhattacharya, N., Black, E., Christensen, T., \& Mergenthaler, R. (2007). Who trades on pro forma earnings information? The Accounting Review, (82), 581-619.

Bhattacharya, N., Christensen, T., Liao, Q., \& Ouyang, B. (2017). Can short sellers constrain aggressive? 
non-GAAP reporting? Working paper. Available at SSRN: 2724935

Black, D., \& Christensen, T. (2009). US managers' use of 'pro forma' adjustments to meet strategic earnings targets. Journal of Business Finance \& Accounting, (36), 297-326.

Black, Dirk E., Christensen, Theodore E., Ciesielski, Jack T., Whipple, Benjamin C. (2017) Non-GAAP Earnings: A Consistency and Comparability Crisis? Tuck School of Business Working Paper No. 2759312. Available at SSRN: https://ssrn.com/abstract=2759312

Bond, D., Czernkowski, R., Lee, Y. S., \& Loyeung, A. (2017). Market reaction to non-GAAP earnings around SEC regulation. Journal of Contemporary Accounting \& Economics, 13(3), 193-208.

Bradshaw, M., \& Sloan, R. (2002). GAAP versus the street: An empirical assessment of two alternative definitions of earnings. Journal of Accounting Research, (40), 41-66.

Bradshaw, M. T., Christensen, T. E., Gee, K. H., \& Whipple, B. C. (2018). Analysts' GAAP earnings forecasts and their implications for accounting research. Journal of Accounting and Economics, (66), 46-66.

Brown, L., \& Sivakumar, K. (2003). Comparing the value relevance of two operating income measures. Review of Accounting Studies, (8), 561-572.

Canadian Securities Administrators (CSA). (2003a). National Instrument 51-102, Continuous Disclosure Obligations. Retrieved from http://www.osc.gov.on.ca/documents/en/SecuritiesCategory5/csa_20160114_52-306_non-gaap.pdf. Accessed April 27, 2018.

Canadian Securities Administrators (CSA). (2003b). CSA Staff Notice: 52-306 - Non-GAAP Financial Measures. Retrieved from Canadian Securities Administrators website: http://www.osc.gov.on.ca/en/13626.htm. Accessed April 27, 2018.

Canadian Securities Administrators (CSA). (2006). Revised CSA Staff Notice: 52-306 - Non-GAAP Financial Measures. Retrieved from CSA website: http://www.osc.gov.on.ca/en/13626.htm. Accessed April 27, 2018.

Canadian Securities Administrators (CSA). (2010). Revised CSA Staff Notice: 52-306 - Non-GAAP Financial Measures and Additional GAAP Measures. Retrieved from CSA website: http://www.osc.gov.on.ca/en/13626.htm. Accessed April 27, 2018.

Canadian Securities Administrators. (2016). CSA Staff Notice 52-306 (Revised) - Non-GAAP Financial Measures. Available at: http://www.osc.gov.on.ca/documents/en/SecuritiesCategory5/csa_20160114_52-306_non-gaap.pdf. Accessed April 27, 2018.

Canadian Securities Administrator (CSA). (2018a). CSA Staff Notice 52-329 Distribution Disclosures and Non-GAAP Financial Measures in the Real Estate Industry. Retrieved from http://www.osc.gov.on.ca/en/SecuritiesLaw_csa_20180412_52-329_distribution-disclosures.htm. Accessed June 13, 2018. 
Canadian Securities Administrators (CSA). (2018b). CSA Staff Notice 51-355 Continuous Disclosure Review Program Activities for the fiscal years ended March 31, 2018 and March 31, 2017. Retrieved from http://www.osc.gov.on.ca/en/SecuritiesLaw_csa_20180719_51-355_continuousdisclosure-review-program.htm. Accessed September 5, 2018.

Canadian Securities Adminstrators (CSA). (2018c). CSA Notice and Request for Comment. Proposed National Instrument 52-112 Non-GAAP and Other Financial Measures Disclosure, Proposed Companion Policy. Retrieved from http://www.osc.gov.on.ca/en/SecuritiesLaw Accessed October 1, 2018.

Canadian Securities Adminstrators (CSA). (2018d). CSA Staff Notice 51-357 Staff Review of Reporting Issuers in the Cannabis Industry. Retrieved from http://www.osc.gov.on.ca/en/SecuritiesLaw Accessed April 17, 2019.

Cannabis Act (2017) Ontario. Retrieved from https://www.ontario.ca/page/Cannabis-legalization. Accessed Feb 3, 2018.

Cazier, R., Christensen, T., Merkley, K., \& Treu, J. (2017). Litigation risk and non-GAAP reporting. Working paper. Available at SSRN: https://ssrn.com/abstract=2928260.

Chen, H., Lee, Y., \& Lo, S. (2017). The information quality of non-GAAP disclosures. Working paper. Available at SSRN: https://ssrn.com/abstract=2921260.

Choi, Y., \& Young, S. (2015). Transitory earnings components and the two faces of non-Generally Accepted Accounting Principles earnings. Accounting \& Finance, (55), 75-103.

Christensen, T., Drake, M., \& Thornock, J. (2014). Optimistic reporting and pessimistic investing: Do pro forma earnings disclosures attract short sellers. Contemporary Accounting Research, 31, 67-102.

Christensen, T., Gomez, E., Ma, M., \& Pan, J. (2017a). Non-GAAP reporting in a shifting information environment. Working paper. Available at SSRN: https://ssrn.com/abstract=2921260.

Christensen, T., Pei, H., Pierce, S., \& Tan, L. (2017b). Non-GAAP reporting following debt covenant violations. Working paper. Available at SSRN: https://ssrn.com/abstract=2575967

Clarkson, P. M., Kao, J. L., \& Richardson, G. D. (1999). Evidence that management discussion and analysis (MD\&A) is a part of a firm's overall disclosure package. Contemporary accounting research, 16(1), 111-134.

Clinch, G., Tarca, A., \& Wee, M. (2018). The value relevance of IFRS earnings totals and subtotals and non-GAAP performance measures. Policy Paper. Available at SSRN: https://ssrn.com/abstract=3178567.

Cole, C. J., \& Jones, C. L. (2005). Management discussion and analysis: A review and implications for future research. Journal of Accounting Literature, 24, 135-174. 
Cooper, D. J., \& Sherer, M. J. (1984). The value of corporate accounting reports: arguments for a political economy of accounting. Accounting, Organizations and Society, 9(3-4), 207-232.

Cormier, D., Demaria, S., \& Magnan, M. (2017). Beyond earnings: do EBITDA reporting and governance matter for market participants? Managerial Finance, 43(2), 193-211.

Coulton, J., Ribeiro, A., Shan, Y., \& Taylor, S. (2016). The rise and rise of non-GAAP disclosure: A survey of Australian practice and its implications. Chartered Accountants Australia and New Zealand and Center for International Finance and Regulation.

Curtis, A. B., McVay, S. E., \& Whipple, B. C. (2013). The disclosure of non-GAAP earnings information in the presence of transitory gains. The Accounting Review, 89(3), 933-958.

Curtis, A., Li, V., \& Patrick, P. (2017). The use of adjusted earnings in performance evaluation. Working paper. Available at SSRN 2682652.

Daske, H. (2006). Economic Benefits of Adopting IFRS or US-GAAP-Have the Expected Cost of Equity Capital Really Decreased? Journal of Business Finance \& Accounting, 33(3-4), 329-373.

Derby, M. (2001). Investors getting more data, but is it the right data? Dow Jones Newswires, September 3.

Donelson, D., Koutney, C., \& Mills, L. (2018). Analyst inattention, transitory tax items, and non-GAAP earnings. Working paper. Available at SSRN: https://ssrn.com/abstract=2720464

Doyle, J. T., Jennings, J. N., \& Soliman, M. T. (2013). Do managers define non-GAAP earnings to meet or beat analyst forecasts? Journal of Accounting and Economics, 56(1), 40-56.

Dye, R. A. (1985). Disclosure of nonproprietary information. Journal of accounting research, 123-145.

Dyreng, S. D., Vashishtha, R., \& Weber, J. (2017). Direct evidence on the informational properties of earnings in loan contracts. Journal of Accounting Research, 55(2), 371-406.

Elliott, W. B. (2006). Are investors influenced by pro forma emphasis and reconciliations in earnings? announcements? The Accounting Review, 81(1), 113-133.

Entwistle, G. M., Feltham, G. D., \& Mbagwu, C. (2005). The voluntary disclosure of pro forma earnings: a US-Canada comparison. Journal of International Accounting Research, 4(2), 1-23.

Frankel, R., \& Roychowdhury, S. (2005). Testing the clientele effect: An explanation for non-GAAP earnings adjustments used to compute I/B/E/S earnings. Working Paper (MIT).

Frankel, R., McVay, S., \& Soliman, M. (2011). Non-GAAP earnings and board independence. Review of Accounting Studies, 16(4), 719-744. 
Frederickson, J. and Miller, J. (2004), The effects of pro forma earnings disclosures on analysts' and non-professional investors' equity valuation judgements The Accounting Review, 79(3), 667-686.

Govendir, B., \& Wells, P. (2013). An evaluation of regulated IFRS and non-IFRS firm performance Measures. The Journal of Applied Science in Southern Africa, (1), 13.

Graham, J. R., Harvey, C. R., \& Rajgopal, S. (2005). The economic implications of corporate financial reporting. Journal of Accounting and Economics, 40(1-3), 3-73.

Gu, Z., \& Chen, T. (2004). Analysts' treatment of nonrecurring items in street earnings. Journal of Accounting and Economics, 38, 129-170.

Guest, Nicholas M., Kothari, S.P. and Pozen, Robert. (2018). High Non-GAAP Earnings Predict Abnormally High CEO Pay. Working Paper. Available at

SSRN: https://ssrn.com/abstract=3030953.

Healy, P. M., \& Palepu, K. G. (2001). Information asymmetry, corporate disclosure, and the capital markets: A review of the empirical disclosure literature. Journal of Accounting and Economics, 31(1-3), 405-440.

Heflin, F., \& Hsu, C. (2008). The impact of the SEC's regulation of non-GAAP disclosures. Journal of Accounting and Economics, (46), 349-365.

Hitz, J. M. (2010). Press release disclosure of 'pro forma'earnings metrics by large German corporationsEmpirical evidence and regulatory recommendations. Accounting in Europe, 7(1), 63-86.

Hoogervorst, H. (2015). Mind the gap (between non-GAAP and GAAP). March 31. Retrieved from http://archive.ifrs.org/Alerts/Conference/Documents/2015/Speech-Hans-Mind-the-Gapspeech-Korea-March-2015.pdf (accessed April 4, 2018).

International Accounting Standards Board (IASB). (2014). IASB finalises amendments to IAS 1 under the Disclosure initiative. Retrieved from https://www.iasplus.com/en/news/2014/12/di-ias-1. Accessed June 12, 2018.

Isidro, H., \& Marques, A. (2013). The effects of compensation and board quality on non-GAAP disclosures in Europe. The International Journal of Accounting, 48(3), 289-317.

Isidro, H., \& Marques, A. (2015). The role of institutional and economic factors in the strategic use of non-GAAP disclosures to beat earnings benchmarks. European Accounting Review, 24(1), 95-128.

Jensen, M. C., \& Meckling, W. H. (1976). Theory of the firm: Managerial behavior, agency costs and ownership structure. Journal of Financial Economics, 3(4), 305-360.

Johnson, W., \& Schwartz, W. (2005). Are investors mislead by "pro forma” earnings? Contemporary Accounting Research, (22), 915-963. 
Kyung, Hangsoo and Weintrop, Joseph (2013). The Economic Consequences of SEC Interpretive Guidance and the Effects on Firm Behavior: Evidence of Non-GAAP Earnings Disclosure (October 10, 2016). CAAA Annual Conference 2013. Available at SSRN: https://ssrn.com/abstract=2200733.

Lee, Y., \& Chu, C. (2016). Causes and consequences of firms' decision to discontinue pro forma earnings information? The Accounting Review, 82(3), 581-619.

Leung, E., \& Veenman, D. (2018). Non-GAAP earnings disclosure in loss firms. Journal of Accounting Research, 56(4), 1083-1137.

Lin, S., \& Walker, M. (2000). FRS3 earnings, headline earnings, and accounting-based valuation models. Accounting and Business Research, (30), 299-306.

Lu, L., \& Shara, N. (2007). Reliability analysis: calculate and compare intra-class correlation coefficients (ICC) in SAS. Northeast SAS Users Group, 14.

Mahoney, L. S., Thorne, L., Cecil, L., \& LaGore, W. (2013). A research note on standalone corporate social responsibility reports: Signaling or greenwashing? Critical Perspectives on Accounting, 24(4-5), 350-359.

Marques, A. (2006), "SEC interventions and the frequency and usefulness of non-GAAP financial measures”, Review of Accounting Studies, Vol. 11, pp. 549-574.

Marques, A. (2017). Non-GAAP earnings: International overview and suggestions for future research. Meditari Accountancy Research, 25(3), 318.

Mohanram, P. S. (2005). Separating winners from losers among low book-to-market stocks using financial statement analysis. Review of Accounting Studies, 10(2), 133-170.

Realpac. (2017). White Papers \& Research - REALPAC. Retrieved from https://www.realpac.ca/page/WhitePapersResea. Accessed July 13, 2018.

Royce Funds. (2016, September 12). Investors: Mind the Gap in GAAP. Retrieved from https://www.roycefunds.com/insights/2016/06/investors-mind-the-gap-in-gaap. Accessed August 19, 2018

Securities and Exchange Commission (SEC) Regulation G (2003). Conditions for Use of Non-GAAP Financial Measures. Retrieved from https://www.sec.gov/rules/final/33-8176.html. Accessed Feb 25, 2018.

Securities and Exchange Commission (SEC) Division of Corporation Finance issues Compliance \& Disclosure Interpretations of regulations on nonGAAP measures (2016). Retrieved from https://www.sec.gov/divisions/corpfin/guidance/nongaap interp.html. Accessed April 15, 2018. 
Securities and Exchange Commission (SEC). (2010). Compliance \& Disclosure Interpretations on Non-GAAP Financial Measures. Retrieved from https://www.sec.gov/divisions/corpfin/guidance/nongaapinterp.html. Accessed April 16, 2018.

Shumsky, T. (2016). IASB chair rings alarm over use of non-GAAP measures. The Wall Street Journal online. Retrieved from https://blogs.wsj.com/cfo/2016/05/11/iasb-chair-rings-alarm-over-use-ofnon-gaap-measures/?mod=djem_jiewr_AC_domain id. Accessed Feb 23, 2018.

Stock, J. H., \& Mark, W. W. (2011). Introduction to Econometrics. New York. Pearson Publishers.

Veritas Investment Research. (2016, September 8). Performance Measurement: The rise of non-GAAP metrics. Retrieved from https://maximizer.veritascorp.com/virdocs/Accounting-Alert-The-Riseof-Non-GAAP-Metrics-Veritas-September-8-2016.pdf. Accessed October 22, 2018

Venter, E. R., Emanuel, D., \& Cahan, S. F. (2014). The value relevance of mandatory non-GAAP earnings. Abacus, 50(1), 1-24.

Wang, G. (2014). The presentation arrangements of pro forma earnings disclosures: Managerial incentives and market responses. Accounting and Finance Research, (3), 27-42.

Wieland, M. M., Dawkins, M. C., \& Dugan, M. T. (2013). The differential value relevance of S\&P's core earnings versus GAAP earnings: the role of stock option expense. Journal of Business Finance \& Accounting, 40(1-2), 55-81. 